Scientia Marina 74(2)

June 2010, 353-370, Barcelona (Spain)

ISSN: 0214-8358

doi: $10.3989 /$ scimar.2010.74n2353

\title{
Faunal and biogeographic analysis of Syllidae (Polychaeta) from Rovinj (Croatia, northern Adriatic Sea)
}

\author{
BARBARA MIKAC ${ }^{1}$ and LUIGI MUSCO ${ }^{2}$ \\ ${ }^{1}$ Center for Marine Research, Ruđer Bošković Institute, Giordano Paliaga 5, 52210 Rovinj, Croatia. \\ ${ }^{2}$ Laboratorio di Biologia Marina e Zoologia, DiSTeBA, Università del Salento, Ecotekne, Via Lecce-Monteroni, \\ 73100 Lecce, Italy. E-mail: luigi.musco@unisalento.it
}

\begin{abstract}
SUMMARY: The study of hard-bottom Syllidae (Polychaeta) of the Rovinj area provides an updated measure of syllid species diversity in the northern Adriatic Sea. Faunal research in the coldest Mediterranean sectors may also help to address possible ecological and biogeographical consequences arising from climate change. Thirty-nine species were found, of which 13 are new for the northern Adriatic, increasing the species recorded from the area from 53 to 66 . Some newly recorded species are dominant and typical of warmer areas. The lack of previous taxonomic updates is responsible for the high number of new findings. However, the northern Adriatic Sea is possibly undergoing long-term changes, with modifications of diversity due to the establishment of warm-water species. Syllid fauna of Sveti Ivan Island and its bioclimatic affinity are, in fact, unexpectedly more similar to the ones of some southern Mediterranean areas than to those traditionally reported for the northern Adriatic.
\end{abstract}

Keywords: syllids, polychaetes, Adriatic Sea, Mediterranean, biogeography, ecology, meridionalization, taxonomic updating.

RESUMEN: ANálisis Faunístico y biogeográfico de los Syllidae (Polychaeta) de Rovinj (Croacia, NORTE det MAR Adriático). - El estudio de los Syllidae (Polychaeta) de los fondos duros del Adriático septentrional, nos ha permitido proporcionar datos actualizados sobre la diversidad de la familia en las costas de Rovinj. Al ser uno de los sectores más fríos del Mediterráneo, el estudio de su fauna representa una contribución al análisis de consecuencias ecológicas y biogeográficas derivadas del calentamiento global. Se han encontrado 39 especies, 13 de ellas nuevas citas para el Adriático septentrional, lo cual incrementa el número de especies conocidas en esta zona a 66. Curiosamente, algunas de estas especies, típicas de áreas más cálidas, son dominantes en la zona de estudio. La falta de una aproximación taxonómica actualizada es, sin duda, uno de los factores más relevantes a la hora de explicar este elevado número de nuevos descubrimientos. Sin embargo, no puede excluirse la posibilidad de que el Adriático septentrional esté sufriendo cambios a largo plazo que afecten a su biodiversidad (incluyendo el asentamiento de especies con afinidad por aguas más cálidas). De hecho, tanto la composición específica de la fauna de sílidos de la Isla Sveti Ivan como su afinidad bioclimática, son inesperadamente más parecidas a las del Mediterráneo meridional que a las del Adriático septentrional.

Palabras clave: sílidos, poliquetos, mar Adriático, Mediterráneo, biogeografía, ecología, meridionalización, taxonomía actualizada.

\section{INTRODUCTION}

The coldest Mediterranean sectors (i.e. Gulf of Lion, northern Adriatic and northern Aegean Seas) are strategic for monitoring faunal changes that may be caused by global warming (Boero et al., 2008).
The northern Adriatic Sea, bordered on the south by the line connecting Pescara in Italy and Zadar in Croatia (McKinney, 2007) is geomorphologically, hydrographically and biogeographically a peculiar Mediterranean region. The lower average temperatures of this northernmost Mediterranean region al- 
lowed the presence of a peculiar flora (e.g. the brown alga Fucus virsoides J. Agardh) and fauna [e.g. the Adriatic sturgeon Acipenser naccarii Bonaparte, 1836, the hydroid Tricyclusa singularis Schulze 1876 and the sprat Sprattus sprattus (L., 1758)]. This supports its strong boreal affinity, as well as its ecological and biogeographical similarities with the North Atlantic (Bianchi et al., 2004; Boero and Bonsdorff, 2007).

Concerning polychaetes, the northern Adriatic Sea hosts the highest percentage of cold-temperate Syllidae species within the Mediterranean, but it also shows the lowest taxonomic updating index (Musco and Giangrande, 2005a). In fact, research on northern Adriatic polychaete fauna started in the second half of the 19th century and continued from the first half of the 20th (see Amoureux, 1983 and literature cited) to the present (Požar-Domac, 1994 and literature cited; Zahtila, 1997; Castelli et al., 1999; Mistri et al., 2002; Aleffi et al., 2003). However, most studies in the literature cover ecological aspects or simply report species lists (including records from grey literature or unpublished data), whereas taxonomic studies are scant. Moreover, most studies deal with soft bottoms, which are dominant on the western Italian coast, whereas very little is known about hard bottoms on the eastern, Istrian coast.

Syllidae is one of the most diverse polychaete families, common in many habitats but typical on hard bottoms. It is also the most diverse polychaete family in the Adriatic Sea, with approximately 100 species (Musco and Giangrande, 2005a). Syllid distribution seems to be a good indicator of local environmental conditions and might be effective in assessing large-scale ecological changes, even over relatively short periods (Giangrande et al., 2004; Musco and Giangrande, 2005a). In fact, some coldwater species previously reported in the northern Adriatic are no longer mentioned (Musco and Giangrande, 2005a). This might indicate an overall warming and tropicalization of the Mediterranean (Bianchi, 2007) causing local extinctions of some sensitive species, but it might also reflect lack of recent, updated taxonomic studies.

Taxonomic studies in the northern Adriatic Sea are, thus, particularly important in this period of global warming, as recently suggested by the CIESM (2008). Therefore, we explored the inshore hard bottoms of the Sveti Ivan Island (Rovinj) to increase knowledge of the northern Adriatic syllid diversity and biogeography. In addition to the inventory of the species found in the area, we also provide drawings, microphotographs and detailed descriptions of the most interesting findings, as an updated faunal background for future research in the area.-

\section{MATERIALS AND METHODS}

\section{Study area, sampling methods and taxonomic approach}

Sveti Ivan Island is located close to Rovinj (Croatia, northern Adriatic Sea), and characterized by calcarenitic rocky plateaus extending from 0 to about $25 \mathrm{~m}$ depth, with a gentle-medium slope. Three stations were sampled in summer 2007 (Fig. 1 ) using scuba diving. At each station, three depths were selected $(1.5 \mathrm{~m}, 5 \mathrm{~m}$ and $25 \mathrm{~m})$, with three replicate samples at each depth by scraping the hard bottom benthos within a 10x10 cm metal frame, for a total of 27 observation units. According to our aims, the airlift sampler was not used in order to limit the mechanical damages and stress, which would induce autotomy in syllids and thus reduce the taxonomic accuracy. At each site temperature and salinity were measured; in situ observations and further analyses of underwater photographs were used to characterize the sessile macrobenthos (Table 1).

Samples were fixed in $8 \%$ formaldehyde seawater solution, sieved through $0.5 \mathrm{~mm}$ mesh and

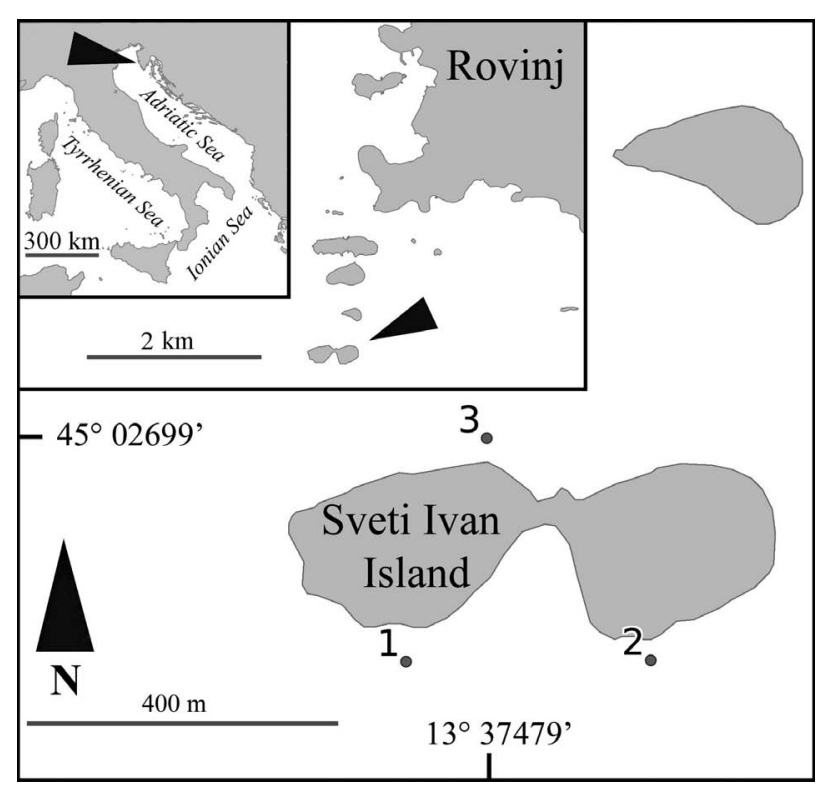

FIG. 1. - Research area. 
TABLE 1. - Research stations, coordinates, depth, sample codes, temperature, salinity and habitat description.

\begin{tabular}{|c|c|c|c|c|c|}
\hline Station & Coordinates & $\begin{array}{l}\text { Depth }(\mathrm{m}) \\
\text { and sample codes }\end{array}$ & Temp $\left({ }^{\circ} \mathrm{C}\right)$ & Salinity & Habitat \\
\hline \multirow[t]{3}{*}{ Sv. Ivan 1} & $\begin{array}{l}\mathrm{N} 45^{\circ} 02.690^{\prime} \\
\mathrm{E} 13^{\circ} 37.180^{\prime}\end{array}$ & $\begin{array}{c}1.5 \mathrm{~m} \\
\mathrm{~A} 1.5(\mathrm{a}, \mathrm{b}, \mathrm{c})\end{array}$ & 25 & 37.91 & $\begin{array}{l}\text { Photophilic algal community (PAC) dominated by } \\
\text { Padina pavonica, Halimeda tuna and Peyssonelia } \\
\text { squamaria; Dyctiota dichotoma and Amphiroa sp. also } \\
\text { present }\end{array}$ \\
\hline & & $\begin{array}{c}5 \mathrm{~m} \\
\mathrm{~A} 5(\mathrm{a}, \mathrm{b}, \mathrm{c})\end{array}$ & 26.8 & 37.91 & $\begin{array}{l}\text { Algal cover dominated by } P \text {. squamaria in the lower } \\
\text { layer and } P \text {. pavonica, Flabelia petiolata, D. dichotoma, } \\
\text { and in low numbers, Jania sp. and Amphiroa sp. in the } \\
\text { upper layer. }\end{array}$ \\
\hline & & $\begin{array}{c}25 \mathrm{~m} \\
\mathrm{~A} 25(\mathrm{a}, \mathrm{b}, \mathrm{c})\end{array}$ & 19.2 & 38.05 & $\begin{array}{l}\text { Peyssonelia sp. and encrusting algae (EA) in the lower } \\
\text { layer, covered by a thick layer formed by Cladophora sp. }\end{array}$ \\
\hline \multirow[t]{3}{*}{ Sv. Ivan 2} & $\begin{array}{l}\mathrm{N} 45^{\circ} 02.699^{\prime} \\
\mathrm{E} 13^{\circ} 37.479^{\prime}\end{array}$ & $\begin{array}{c}1.5 \mathrm{~m} \\
\mathrm{~B} 1.5(\mathrm{a}, \mathrm{b}, \mathrm{c})\end{array}$ & 26.4 & 37.98 & $\begin{array}{l}\text { PAC dominated by } P \text {. pavonica, D. dichotoma and } \\
\text { Laurentia obtusa. Calcareous substrate inhabited by the } \\
\text { bivalves Lithophaga lithophaga and Rocelaria dubia. }\end{array}$ \\
\hline & & $\begin{array}{c}5 \mathrm{~m} \\
\mathrm{~B} 5(\mathrm{a}, \mathrm{b}, \mathrm{c})\end{array}$ & 26.4 & 37.93 & $\begin{array}{l}\text { Sciaphylous habitat; dominated by sponges (possibly } \\
\text { Ircinia sp.) and the algae P. squamaria and EA, in the } \\
\text { lower layer, and D. dichotoma, P. pavonica, F. petiolata } \\
\text { and Jania sp. (and in low numbers Amphiroa sp. and } \\
\text { Cladophora sp.) in the upper layer. }\end{array}$ \\
\hline & & $\begin{array}{c}25 \mathrm{~m} \\
\mathrm{~B} 25(\mathrm{a}, \mathrm{b}, \mathrm{c})\end{array}$ & 20.6 & 37.97 & $\begin{array}{l}\text { Spirastrella sp. sponge, compound Ascidian (possibly } \\
\text { Botrylloides sp.), EA. }\end{array}$ \\
\hline \multirow[t]{3}{*}{ Sv. Ivan 3} & $\begin{array}{l}\mathrm{N} 45^{\circ} 02.768^{\prime} \\
\mathrm{E} 13^{\circ} 37.639^{\prime}\end{array}$ & $\begin{array}{c}1.5 \mathrm{~m} \\
\mathrm{C} 1.5(\mathrm{a}, \mathrm{b}, \mathrm{c})\end{array}$ & 25.2 & 37.95 & $\begin{array}{l}\text { PAC completely covered by Corallina officinalis in the } \\
\text { bottom layer; dominant algae in the upper layer are } P \text {. } \\
\text { pavonica and } D \text {. dichotoma (with Laurentia sp. and } \\
\text { Amphiroa sp. present in low numbers). }\end{array}$ \\
\hline & & $\begin{array}{c}5 \mathrm{~m} \\
\mathrm{C} 5(\mathrm{a}, \mathrm{b}, \mathrm{c})\end{array}$ & 24.8 & 37.96 & $\begin{array}{l}\text { Dominance of } P . \text { squamaria in the bottom layer and } P \text {. } \\
\text { pavonica, } D \text {. dichotoma, Galaxaura oblongata, Jania sp. } \\
\text { and encrusting algae in the upper layer. }\end{array}$ \\
\hline & & $\begin{array}{c}25 \mathrm{~m} \\
\mathrm{C} 25(\mathrm{a}, \mathrm{b}, \mathrm{c})\end{array}$ & 22.4 & 37.95 & EA, and other unidentified low growing algae. \\
\hline
\end{tabular}

preserved in $70 \%$ ethanol. Syllids were sorted under a stereomicroscope. Diagnostic characters were analysed, drawn and photographed under an optical microscope. Specimen width at proventricle level, excluding parapodia, and length of prostomium plus first 10 chaetigers $(\mathrm{H}+10)$ were measured. The following abbreviations are used throughout the text: DC (dorsal cirrus/dorsal cirri), Chr (chaetiger/ chaetigers). In the taxonomic accounts, only the most recent literature on species description (also providing synonymies and references) is given. All specimens are deposited at the Center for Marine Research of the Ruđer Bošković Institute in Rovinj, Croatia.

\section{Biogeographic and ecological analyses}

Using the checklists of the coastlines of the northern Adriatic, Spain, northwest Italy, eastern Sicily, Israel, Cyprus, the Turkish and Greek Aegean, and the Ionian and Adriatic coastlines of the Salento
Peninsula reported in the recent biogeographic revision of the Mediterranean Syllidae (Musco and Giangrande, 2005a), the Sveti Ivan syllid species inventory was compared with those of the above-mentioned coastlines both faunistically (i.e. comparing the syllid species lists based on a presence/absence matrix) and bioclimatically, assigning the species to 6 bioclimatic categories: cold, temperate-cold, temperate, temperate-warm, warm and eurythermic. Differences among inventories were assessed by means of the Bray Curtis similarity index and multidimensional scaling (MDS) analysis (PRIMER, Plymouth Marine Laboratory, UK).

In the Sveti Ivan syllid assemblages, differences in the spatial distribution of the individuals and the species richness were tested by analysis of variance (ANOVA). Differences in the spatial distribution of the species richness grouped in bioclimatic categories were tested by permutational multivariate analysis of variance (PERMANOVA) using the PERMANOVA computer program (Anderson, 2005). 
TABLE 2. - Univariate and multivariate analysis of variance testing differences in the spatial distribution of the syllid assemblages [Factor 1: station (St), three levels, random; Factor 2: depth (De), three levels, orthogonal, fixed; Three replicates]. A, differences in spatial distribution of individuals and species richness (ANOVA, untransformed data). B, differences in spatial distribution of species richness grouped in bioclimatic categories (PERMANOVA based on Bray-Curtis dissimilarity, untransformed data). DF, degrees of freedom; MS, mean square; F, F-ratio; pu, permutable units; MS $_{\text {denom }}$, denominator mean square. Significant p-values are in italics.

\begin{tabular}{|c|c|c|c|c|c|c|c|c|c|}
\hline \multirow{2}{*}{$\begin{array}{l}\text { A } \\
\text { Source }\end{array}$} & \multicolumn{3}{|c|}{$\begin{array}{l}\text { Syllidae individuals } \\
\text { (Cochran's test NS) }\end{array}$} & \multicolumn{4}{|c|}{$\begin{array}{l}\text { Syllidae species } \\
\text { (Cochran's test NS) }\end{array}$} & \multirow[b]{2}{*}{$\mathrm{p}$} & \multirow[b]{2}{*}{$\mathrm{MS}_{\text {denom }}$} \\
\hline & $\mathrm{DF}$ & MS & $\mathrm{F}$ & $\mathrm{p}$ & & MS & $\mathrm{F}$ & & \\
\hline St & 2 & 469.93 & 2.37 & 0.1218 & & 38.48 & 4.48 & 0.0264 & Res \\
\hline $\mathrm{De}$ & 2 & 283.81 & 0.55 & 0.6172 & & 43.81 & 8.16 & 0.0388 & St $x$ De \\
\hline St $x$ De & 4 & 520.04 & 2.62 & 0.0690 & & 5.37 & 0.63 & 0.6507 & Res \\
\hline Residuals & 18 & 198.11 & & & & 8.59 & & & \\
\hline $\mathrm{B}$ & \multicolumn{3}{|c|}{ Bioclimatic categories } & & & & & & \\
\hline Source & $\mathrm{DF}$ & MS & $\mathrm{F}$ & $\mathrm{p}_{\text {(perm) (1) }}$ & $\mathrm{MS}_{\text {denom }}$ & p.u. & & & \\
\hline St & 2 & 1915.29 & 6.2559 & 0.0004 & Res & 27 & & & \\
\hline De & 2 & 1415.07 & 3.3845 & 0.0510 & St $x$ De & 9 & & & \\
\hline St $x$ De & 4 & 418.10 & 1.3656 & 0.2260 & Res & 27 & & & \\
\hline Residuals & 18 & 306.16 & & & & & & & \\
\hline
\end{tabular}

(1) Test done using 4999 permutations of appropriate units, the p-value given in bold was obtained using 4999 Monte Carlo samples from the asymptotic permutation distribution.
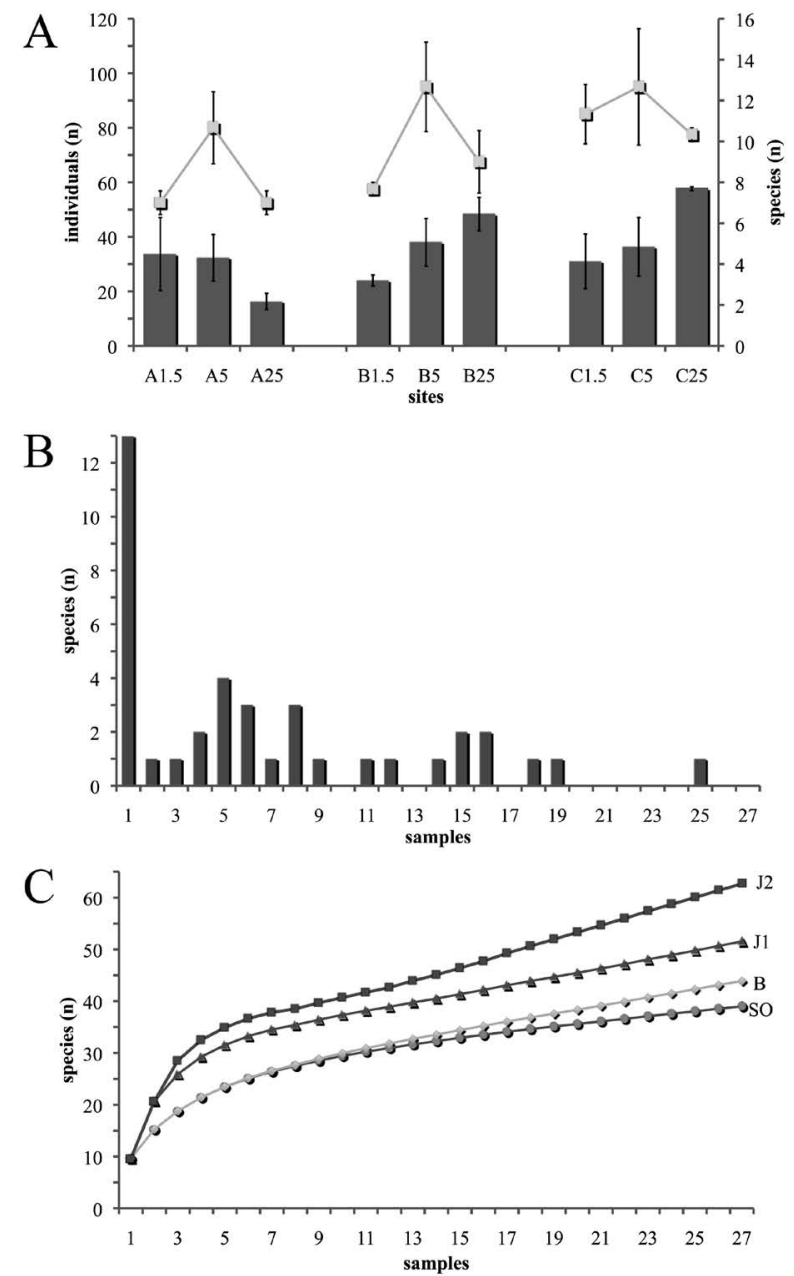

FIG. 2. - Species distribution pattern in the sampled area. A, mean number ( $\pm \mathrm{SE}, \mathrm{n}=3$ ) of syllid individuals (bars) and species (lines) at the analyzed sites. B, distribution of species according to the number of replicates occupied. $\mathrm{C}$, species area accumulation curve and estimator curves (J1, Jacknife1; J2, Jacknife2; B, Bootstrap; SO, Species observed).

\section{RESULTS}

\section{Diversity and biogeography}

From a total of 39 species, 27 (266 specimens) were found at $1.5 \mathrm{~m}, 28$ (320 specimens) at $5 \mathrm{~m}$ and 22 (367 specimens) at $25 \mathrm{~m}$ depth. The mean number of species per sample was always higher but also more variable at $5 \mathrm{~m}$ depth; the mean number of individuals was higher at $25 \mathrm{~m}$ depth at station $\mathrm{B}$ and $\mathrm{C}$, while the minimum abundance was observed at the same depth at station A (Fig. 2A). The ANOVA (Table 2A) revealed significant differences in the local distribution of the species richness both vertically (among depths) and horizontally (among stations). Most species were locally rare (Fig. 2B), with 13 out of 39 being found only in one sample, and only Sphaerosyllis pirifera being common in the whole area ( 25 samples). Consequently, neither the accumulation curve, nor the estimator curves (Jacknife1, Jacknife2, Bootstrap) showed a tendency to reach the asymptote (Fig. 2C), suggesting a potentially large number of species for the area (i.e. from 44 to 63). Based on their abundance, twelve species are considered as the most representative of the area (Table 3).

From a bioclimatic point of view, about $38 \%$ of the species were temperate-warm, $28 \%$ eurythermic, $23 \%$ temperate, $7 \%$ temperate cold and $3 \%$ warm, while none of them was cold. PERMANOVA revealed significant differences in the horizontal distribution of the richness of species grouped in bioclimatic categories (among stations), but no differences among depths (Table 2B). 
TABLE 3. - Mean number of individuals (mean) per sampling unit $\left(0.01 \mathrm{~m}^{2}\right)$ plus standard deviation (SD) of the 12 most abundant syllid species at $1.5,5$ and $25 \mathrm{~m}$ deep. Total: number of collected individuals; *: new for the area

\begin{tabular}{|c|c|c|c|c|c|c|c|}
\hline & \multicolumn{2}{|c|}{$1.5 \mathrm{~m}$} & \multicolumn{2}{|c|}{$5 \mathrm{~m}$} & \multicolumn{2}{|c|}{$25 \mathrm{~m}$} & \multirow[t]{2}{*}{ total } \\
\hline & mean & SD & mean & SD & mean & SD & \\
\hline Sphaerosyllis pirifera * & 4.67 & 5.72 & 5.67 & 4.06 & 8.78 & 8.66 & 172 \\
\hline Syllis armillaris & 1.00 & 1.22 & 1.89 & 2.15 & 13.22 & 8.36 & 145 \\
\hline Syllis prolifera & 5.44 & 7.28 & 5.33 & 5.39 & 1.00 & 1.80 & 106 \\
\hline Syllis gracilis & 0.22 & 0.67 & 0.67 & 0.87 & 6.67 & 3.61 & 68 \\
\hline Syllis rosea * & 7.00 & 12.34 & 0.44 & 0.53 & & & 67 \\
\hline Syllis gerlachi* & 0.22 & 0.44 & 3.00 & 4.00 & 4.11 & 3.22 & 66 \\
\hline Exogone dispar & 2.89 & 3.18 & 3.67 & 2.50 & 0.11 & 0.33 & 60 \\
\hline Syllis variegata & 0.33 & 0.50 & 3.33 & 2.06 & 1.56 & 1.74 & 47 \\
\hline Syllis corallicola $*$ & 1.00 & 2.65 & 3.11 & 2.47 & 0.44 & 0.53 & 41 \\
\hline Odontosyllis ctenostoma & 0.33 & 0.71 & 2.44 & 3.00 & & & 25 \\
\hline Syllis westheidei * & 1.56 & 2.55 & 0.89 & 1.27 & & & 22 \\
\hline Haplosyllis spongicola & 0.11 & 0.33 & 0.89 & 1.62 & 0.89 & 0.93 & 17 \\
\hline
\end{tabular}

The faunistic analysis (Fig. 3A) shows that Sveti Ivan is just opposite the northern Adriatic, whereas the other Mediterranean sectors are in an intermediate position, forming two groups (SP, NWI, GR, TU, CY, SA, SI and ES, IS). In turn, the bioclimatic

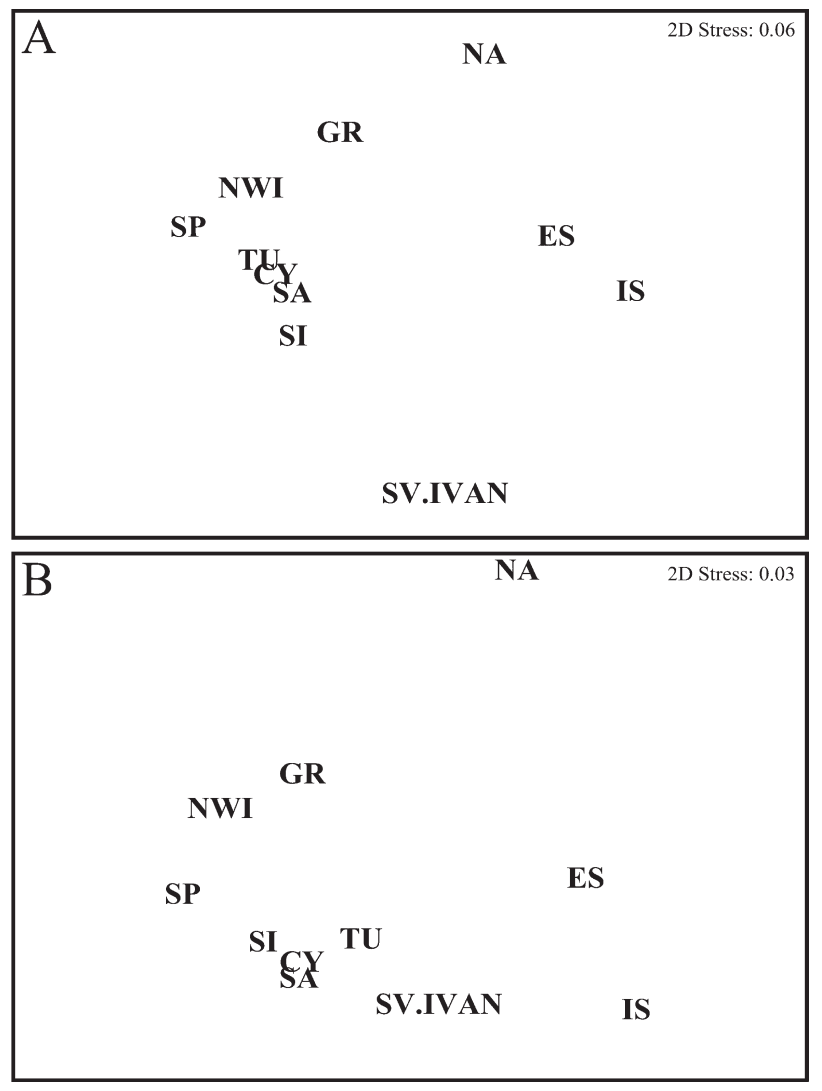

FIG. 3. - MDS analyses (Bray-Curtis Similarity) comparing the Sv. Ivan Island syllid fauna to those of the ten Mediterranean coastlines following Musco and Giangrande (2005a). A, faunistic comparison. B, bioclimatic comparison. NA, N Adriatic; SP, Spanish; NWI, NW Italian; ES, E Sicilian; IS, Israeli; CY, Cypriot; TU, Turkish Aegean; GR, Greek Aegean coastlines; SI, the Ionian; and SA, the Adriatic coastlines of the Salento Peninsula. analysis confirms the differences between the northern Adriatic and the remaining coasts, while Sveti Ivan most closely resembles the southern Mediterranean (Fig. 3B).

\section{Taxonomic account}

Family SylLidae Grube, 1850

Subfamily Autolytinae Grube, 1850

Genus Epigamia Nygren, 2004

Epigamia macrophtalma (Marenzeller, 1875)

Epigamia macrophtalma, Nygren, 2004: 172

Material: C1.5a, 1 ind.

Distribution: Mediterranean Sea (Nygren, 2004).

Genus Myrianida Milne Edwards, 1845

Myrianida brachycephala (Marenzeller, 1874)

Myrianida brachycephala, Nygren, 2004: 120

Material: A5b, 1ind.; A5c, 1 ind.; A25a, 3 ind.; A25b, 1 ind.; B25c, 1 ind.; C5b, 3 ind.; C5c, 1 ind.

Distribution: Mediterranean Sea, N Atlantic Ocean (Nygren, 2004).

\section{Myrianida convoluta (Cognetti, 1953)}

Myrianida convoluta, Nygren, 2004: 125

Material: C25b, 1 ind.

Distribution: Mediterranean Sea, N Atlantic and N Pacific Ocean (Nygren, 2004). New for the N Adriatic Sea. 
Myrianida edwarsi (Saint-Joseph, 1887)

Myrianida edwarsi, Nygren, 2004: 128

Material: A1.5b, 1 ind.; A5a, 1 ind.; A5c, 3 ind.; B25b, 1 ind.; C5b, 1 ind.; C5c, 2 ind.

Distribution: Mediterranean Sea, NE Atlantic Ocean (Nygren, 2004).

Myrianida quindecimdentata (Langerhans, 1884)

Myrianida quindecimdentata, Nygren, 2004: 153

Material: C5c, 1 ind.

Distribution: Mediterranean and Red Sea, NE Atlantic Ocean (Nygren, 2004). New for the N Adriatic Sea.

Myrianida rubropunctata (Grube, 1860)

Myrianida rubropunctata, Nygren, 2004: 156

Material: C25c, 4 ind.

Distribution: Mediterranean Sea, NE Atlantic Ocean (Nygren, 2004).

Genus Proceraea Ehlers, 1864

Proceraea aurantiaca Claparède, 1868

Proceraea aurantiaca, Nygren, 2004: 44

Material: A1.5a, 2 ind.

Distribution: Mediterranean Sea, NE Atlantic Ocean (Nygren, 2004).

Subfamily Exogoninae Langerhans, 1879

Genus Brania Quatrefages, 1866

Brania pusilla (Dujardin, 1839)

Brania pusilla, San Martín, 2003: 151

Material: C5b, 1 ind.

Distribution: Mediterranean Sea, W Atlantic and E Atlantic Ocean from the North Sea to South Africa, Indian coast of South Africa, Australia (San Martín, 2005).

Genus Exogone Örsted, 1845

Subgenus Exogone (Exogone) Örsted, 1845

Exogone (Exogone) dispar (Webster, 1879)

Exogone (Exogone) dispar, San Martín, 2003: 274
Material: A1.5a, 6 ind.; A1.5b, 3 ind.; A1.5c, 1 ind.; A5a, 5 ind.; A5b, 2 ind.; A5c, 2 ind.; A25b, 1 ind.; B5a, 2 ind.; B5b, 3 ind.; B5c, 2 ind.; C1.5a, 2 ind.; C1.5b, 9 ind.; C1.5c, 5 ind.; C5a, 2 ind.; $C 5 b$, 6 ind.; $\mathrm{C} 5 \mathrm{c}, 9$ ind.

Distribution: Mediterranean Sea, W Atlantic Ocean from Arctic to Florida, Pacific Ocean (Galápagos Islands, Japan, W Australia), South Africa (San Martín, 2005).

\section{Exogone (Exogone) rostrata Naville, 1933}

Exogone rostrata, San Martín, 2003: 265

Material: A25c, 1 ind.; B5c, 1 ind.; B25b, 1 ind.; C25b, 2 ind.

Remarks: Exogone rostrata is easily distinguishable from the congenerics in the area due to the special spiniger-like chaeta from chaetiger 1 , with a long blade and stout handle ending with a triangular ridge forming a cup-shaped structure.

Distribution: Mediterranean Sea (San Martín, 2003). New for the N Adriatic Sea.

Genus Salvatoria McIntosh, 1885

Salvatoria clavata (Claparède, 1863)

Salvatoria clavata, San Martín, 2003: 176

Material: A1.5b, 1 ind.

Distribution: Cosmopolitan (San Martín, 2003).

Genus Sphaerosyllis Claparède, 1863

Sphaerosyllis hystrix Claparède, 1863

Sphaerosyllis hystrix, San Martín, 2003: 203

Material: A1.5b, 2 ind.; B1.5b, 1 ind.; C1.5a, 1 ind.; C5c, 2 ind.

Distribution: The species is considered cosmopolitan. However, its distributional range should possibly be limited to the E Atlantic Ocean (from Europe to North Africa) and the Mediterranean Sea (San Martín, 2003).

Sphaerosyllis pirifera Claparède, 1868

(Fig. 4)

Sphaerosyllis pirifera, San Martín, 2003: 212

Material: A1.5a, 18 ind.; A1.5b, 7 ind.; $\mathrm{A} 1.5 \mathrm{c}, 1$ ind.; $\mathrm{A} 5 \mathrm{a}, 2$ ind.; A5b, 2 ind.; A5c, 6 ind.; A25a, 1 ind.; A25b, 1 ind.; A25c, 3 ind.; $\mathrm{B} 1.5 \mathrm{c}, 1$ ind.; B5a, 6 ind.; B5b, 2 ind.; B5c, 5 ind.; B25a, 4 ind.; B25b, 19 ind.; B25c, 2 ind.; C1.5a, 3 ind.; C1.5b, 5 ind.; C1.5c, 7 

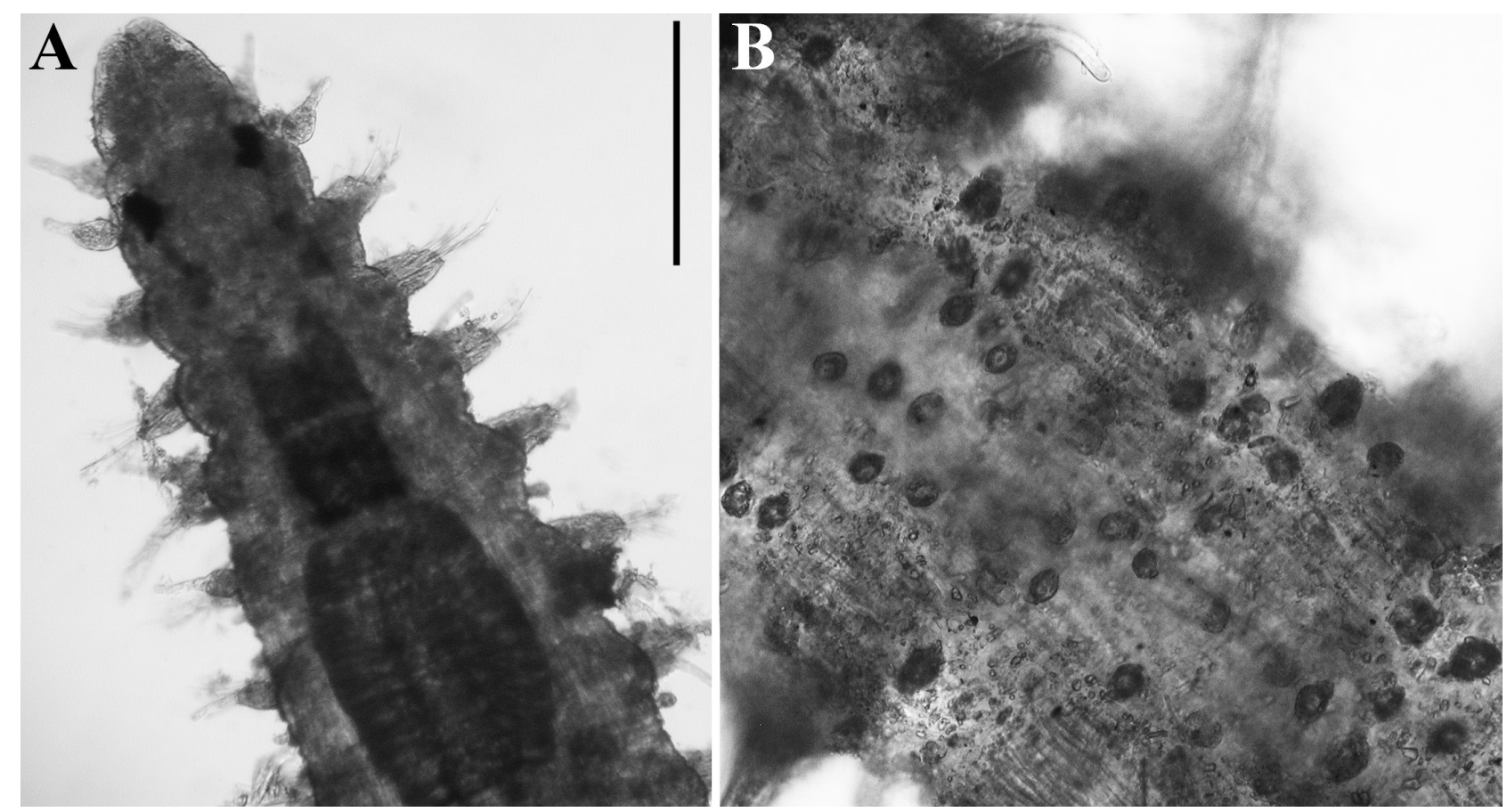

FIG. 4. - Sphaerosyllis pirifera. A, anterior end, dorsal view; B, dorsal papillae. Scale bars: A, $200 \mu \mathrm{m} ; \mathrm{B}, 100 \mu \mathrm{m}$.

ind.; C5a, 10 ind.; C5b, 14 ind.; C5c, 4 ind.; C25a, 24 ind.; C25b, 10 ind.; $\mathrm{C} 25 \mathrm{c}, 15$ ind.

Description: Largest specimen complete, $4.86 \mathrm{~mm}$ for $38 \mathrm{Chr}$ the largest, $0.28 \mathrm{~mm}$ wide, $\mathrm{H}+10=1.12$ mm (Fig. 4A). Body pale-brownish, covered by debris. Dorsum with rounded, large papillae somewhat arranged in rows, both in antero-posterior and lateral direction (Fig. 4B). Papillae on palps and parapodial lobes. Parapodial glands absent. Peristomium almost as long as Chr 1, partially covering prostomium. Antennae, DC and tentacular cirri pyriform. Bulb of cirri much elongated toward the pygidium. Seven compound unidentate chaetae in anterior parapodia (blades 12-30 $\mu \mathrm{m}$ ), number of chaetae and dorsoventral gradation in blade lengths reducing toward the pygidium. Dorsal simple chaeta unidentate, marginally serrated. Ventral simple chaeta curved, unidentate, smooth. Aciculae one in posterior parapodia, bending at a right angle, two in anterior parapodia (one straight, one similar to the posterior one). Proventricle barrel shaped extending for three segments (Chr 4-6), with 14 muscular cell rows (Fig. 4A). Pharynx darkbrownish, with an anterior conical tooth.

Remarks: Sphaerosyllis pirifera was the most abundant species at all depths and stations. Moreover, it is the largest Mediterranean Sphaerosyllis species and has never been previously mentioned in the area.
Distribution: Mediterranean Sea, E Atlantic Ocean (San Martín, 2003). New for the N Adriatic Sea.

Subfamily Eusyllinae Malaquin, 1893 (sensu San Martín, 2003)

Genus Amblyosyllis Grube, 1857

Amblyosyllis formosa (Claparède, 1863)

Amblyosyllis formosa, San Martín, 2003: 93

Material: C5b, 1 ind.

Distribution: Mediterranean and Black Sea, N Atlantic Ocean, South Africa, Japan (San Martín, 2003).

Genus Eusyllis Malmgren, 1867

Eusyllis lamelligera Marion and Bobretzky, 1875

Eusyllis lamelligera, San Martín, 2003: 117

Material: C1.5b, 2 ind.

Distribution: Mediterranean Sea, N Atlantic Ocean, Australia (San Martín and Hutchings, 2006).

Genus Odontosyllis Claparède, 1863

Odontosyllis ctenostoma Claparède, 1868

Odontosyllis ctenostoma, San Martín, 2003: 107; Musco et al., 2008: 423 
Material: A5a, 1 ind.; A5b, 8 ind.; A5c, 3 ind.; B1.5a, 2 ind.; B1.5c, 1 ind.; B5b, 1 ind.; B5c, 7 ind.; C5b, 1 ind.; C5c, 1 ind.

Distribution: Mediterranean Sea, E Atlantic Ocean (San Martín, 2003).

Odontosyllis fulgurans (Audouin and Milne-Edward, 1834)

Odontosyllis fulgurans, San Martín, 2003: 104

Material: C25a, 1 ind.

Distribution: The species is considered cosmopolitan in warm-temperate areas. However, its distributional range should possibly be limited to the E Atlantic Ocean and the Mediterranean Sea (San Martín, 2003).

Genus Paraehlersia San Martín, 2003

Paraehlersia ferrugina (Langerhans, 1881)

Paraehlersia ferrugina, San Martín, 2003: 61

Material: A1.5a, 1 ind.; A25c, 1 ind.; B1.5a, 1 ind.; B1.5b, 1 ind.; $\mathrm{B} 1.5 \mathrm{c}, 1$ ind.; $\mathrm{C} 1.5 \mathrm{a}, 2$ ind.

Distribution: The species is considered cosmopolitan in warm-temperate areas (San Martín, 2003).

\section{Paraehlersia cf. dionisi (Núñez and San Martín, 1991) (Fig. 5)}

? Pionosyllis dionisi Núñez and San Martín, 1991: 236; San Martín, 2003: 67

Material: B25b, 1 ind.

Description: Specimen incomplete, $16 \mathrm{Chr}, 1.72$ $\mathrm{mm}$ long, $0.44 \mathrm{~mm}$ wide, $\mathrm{H}+10=0.98 \mathrm{~mm}$. Prostomium pentagonal with two separated pairs of eyes in open trapezoidal arrangement and two ocular specks (Fig. 5A). Palps long, $0.16 \mathrm{~mm}$, triangular, fused at base. Median antenna lost, slightly ahead posterior pair of eyes. Lateral antennae with about 13 articles, $0.2 \mathrm{~mm}$ long. Peristomium as long as Chr 1. Dorsal tentacular cirri lost; ventral tentacular cirri weakly articulated, $0.12 \mathrm{~mm}$ long. First and second DC weakly articulated; first DC as long as lateral antennae, thinner; DC 2 half long as DC 1, thinner. From Chr 8-10, DC stouter, alternating in length: at proventricular level shorter cirri very short, almost club shaped, as long as parapodial lobe, smooth; longer cirri smooth, stout, twice as long as short ones. Ventral cirri digitiform, as long as parapodial lobe. Para-

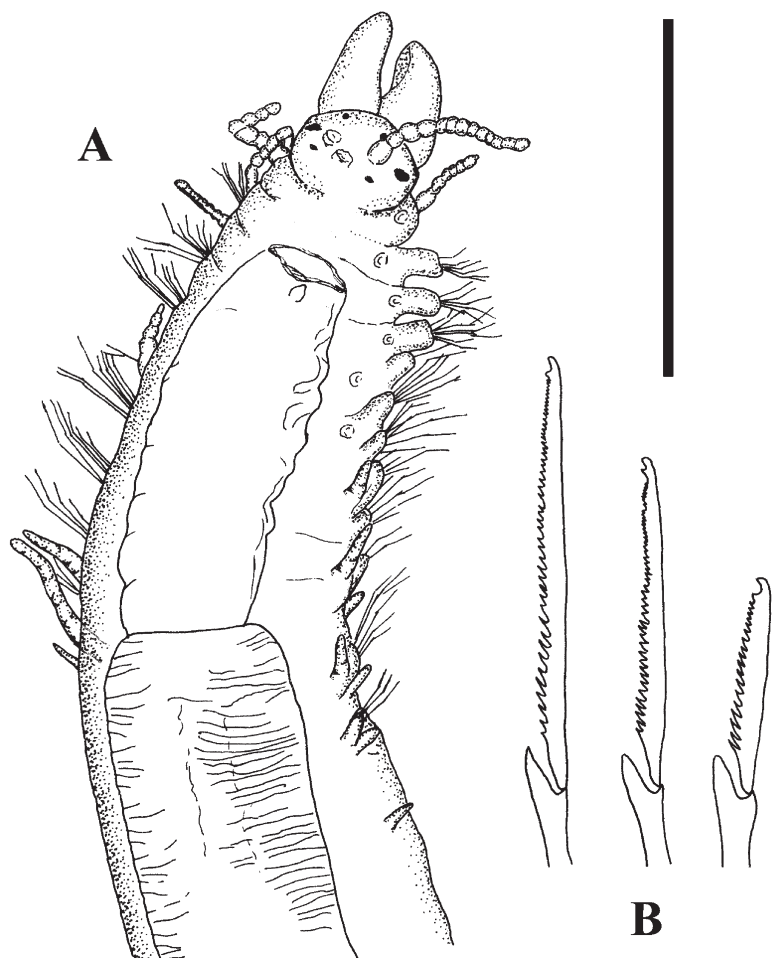

FIG. 5. - Paraehlersia cf. dionisi. A, anterior end, dorsal view; B, anterior chaetae. Scale bars: A, $500 \mu \mathrm{m}$; B, $50 \mu \mathrm{m}$.

podial lobes almost cylindrical. Compound chaetae with bidentate blades; three long bladed (44 $\mu \mathrm{m}$ long), 7-9 short-bladed ( $23 \mu \mathrm{m}$ long) chaetae in first 10-12 Chr (Fig. 5B); long-bladed chaetae gradually longer when posterior-most: two long bladed (58 $\mu \mathrm{m}$ long), 5 short bladed ( $21 \mu \mathrm{m}$ long) at Chr 16. Aciculae four in anterior parapodia, two in Chr 14-16 (one with expanded head and acuminate tip). Proventricle rectangular to barrel shaped, $0.25 \mathrm{~mm}$ wide, extending for 6 segments (Chr 9-14), with 29 muscle cell rows. Pharynx yellowish-brownish, extending from Chr 2-8 (Fig. 5A), with anterior tooth triangular to drop-shaped.

Remarks: The specimen resembles Paraehlersia (?) dionisi (Núñez and San Martín, 1991) but differs in having shorter dorsal cirri at proventricular level, shorter long-bladed chaetae (up to $58 \mu \mathrm{m}$ vs $80 \mu \mathrm{m}$ in the original description) and particularly in having a longer peristomium (as long as Chr 1 vs very short, covered by the Chr 1 in the original description). This species is included in Paraehlersia since the antennae, tentacular and anterior cirri are articulated, and it has spiniger-like compound chaetae; however, its systematic position remains unclear, being thus indicated as P. (?) dionisi (San Martín et al., 2009). 
Distribution: E Atlantic Ocean, Mediterranean Sea (Spanish and Turkish coast) and Antarctica. It was found in Mediterranean from 43 to $470 \mathrm{~m}$ depth (San Martín, 2003). Providing our specimen actually belongs to $P$. (?) dionisi, this would be the first record for the Adriatic Sea and the shallowest one, since it was found at $25 \mathrm{~m}$ depth.

Genus Synmerosyllis San Martín, López and Aguado, 2009

Synmerosyllis lamelligera (Saint-Joseph, 1887)

Pionosyllis lamelligera, San Martín, 2003: 79

Material: A1.5a, 1 ind.; B5c, 1 ind.

Distribution: Mediterranean Sea, Atlantic Ocean (San Martín, 2003). New for the N Adriatic Sea.

Genus Nudisyllis Knox and Cameron, 1970 Nudisyllis pulligera (Krohn, 1852)
Pionosyllis pulligera, San Martín, 2003: 82

Material: B1.5b, 1 ind.

Remarks: San Martín and Hutchings (2006) emended Nudisyllis and transferred in this genus some species previously considered to belong to Pionosyllis Malmgren, 1867, including P. pulligera (Krohn, 1852).

Distribution: Mediterranean and Red Sea, NE Atlantic Ocean (San Martín et al., 2009).

Subfamily Syllinae Grube, 1850

Genus Branchiosyllis Ehlers, 1887

Branchiosyllis exilis (Gravier, 1900) sensu San Martín, 1984 (Fig. 6)

? Syllis (Typosyllis) exilis Gravier, 1900: 160

Branchiosyllis exilis, San Martín, 1984: 294, 2003: 332

? Branchiosyllis exilis, San Martín et al., 2008a: 127

Material: B1.5c - 1 ind.; B5c - 2 ind.; C5a -1 ind.
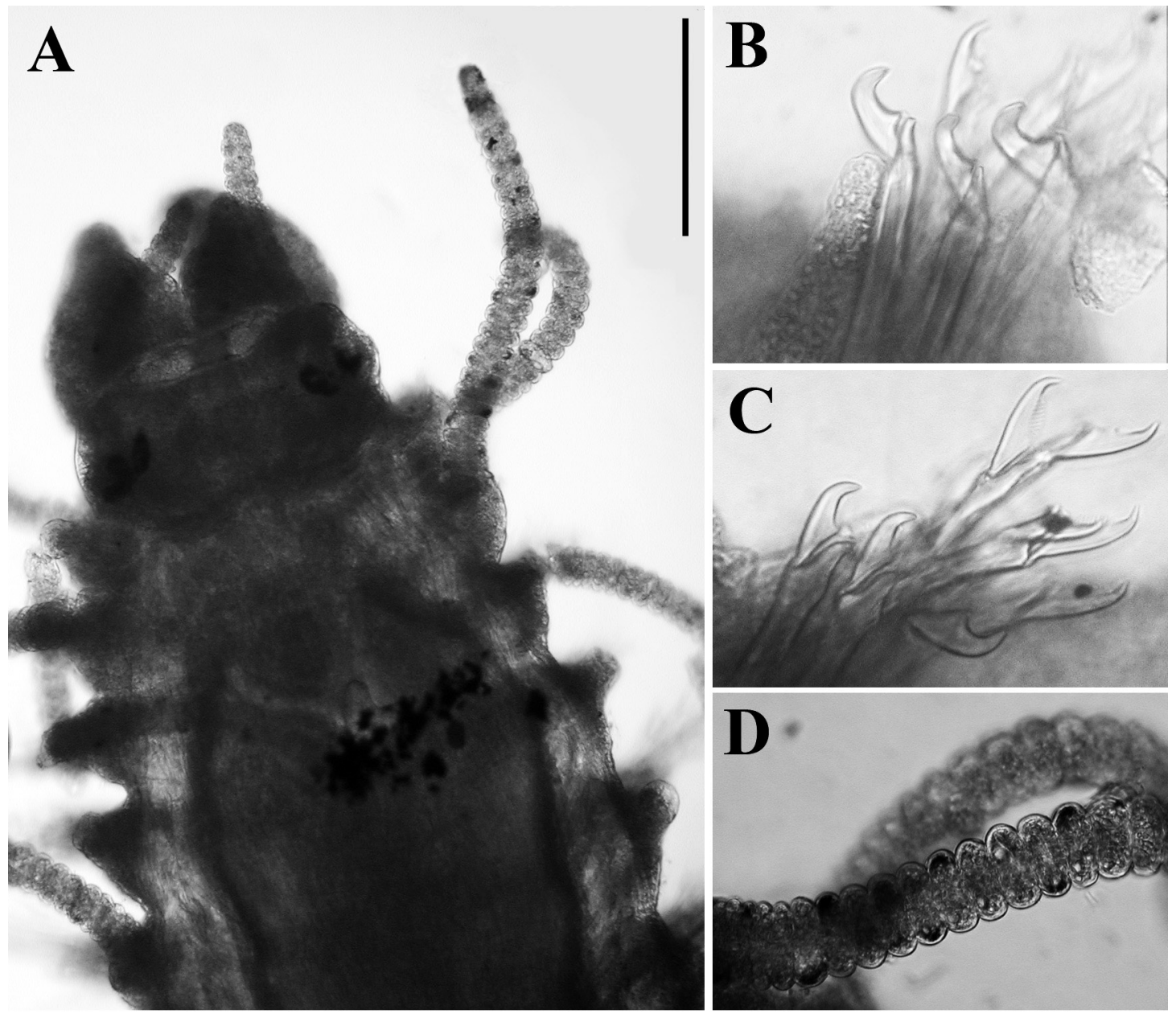

FIG. 6. - Branchiosyllis exilis. A, anterior end, dorsal view; B, mid-body chaetiger (25) with chaetae; C, mid-posterior chaetiger (40) with chaetae; D, dorsal cirri. Scale bars: A, $200 \mu \mathrm{m}$; B-C, $50 \mu \mathrm{m}$; D, $100 \mu \mathrm{m}$. 
Description: Largest specimen incomplete, 8.3 $\mathrm{mm}$ long for $42 \mathrm{Chr}, 0.6 \mathrm{~mm}$ wide, $\mathrm{H}+10=1.6 \mathrm{~mm}$ (Fig. 6A). Dark colour marks on the dorsum; dark spots on the lateral edge of articles on DC and dorsal tentacular cirri, alternating in left/right position (Fig. 6D). Median antenna with15 articles; lateral ones with 13 articles. Peristomium, about half wide as Chr 1. Ventral tentacular cirri with 13 articles, dorsal slightly longer. Articles of cirri squeezed-ball shaped numbering 30 in DC 1, 19 in DC2. Anterior parapodia each with 8 compound bidentate chaetae with distinct dorso-ventral gradation in lengths; subdistal tooth decreasing in size backwards. From $\mathrm{Chr}$ 18-20, chaetae mostly unidentate (Fig. 6B). Clawshaped chaetae (blade turned out $180^{\circ}$ with respect to shaft) starting from Chr 26 (Fig. 6C). Aciculae numbering three anteriorly, two backwards. Proventricle with 36 muscle cell rows. Tooth conical anteriorly on the pharynx. One female with coelomic eggs, starting from Chr 17.

Remarks: Our specimens correspond to the descriptions of San Martín (1984; 2003). However, the dark spots on antennae and cirri were not reported in the holotype either by Gravier (1900) or by San Martín et al. (2008a). Other species having dark spots on cirri and similar chaetae are $B$. thylacine San Martín et al., 2008a,b, B. cirropunctata Michel, 1909 and B. maculata (Imajima, 1966). The first two, however, differ from our specimens in the shape of anterior falcigers, while $B$. maculata differs in having longer antennae and DC. Branchiosyllis exilis is considered a species complex and would require a detailed revision. Our specimens, as well as the Iberian ones, might belong to a different species (San Martín et al., 2008a).

Distribution: The B. exilis species complex, as well as the genus Branchiosyllis, has a circumtropical distribution, including the warmer areas of the Mediterranean Sea (San Martín et al., 2008a). This is the northernmost record in the Mediterranean area.

Genus Eurysyllis Ehlers, 1864

Eurysyllis tuberculata Ehlers, 1864

Eurysyllis tuberculata, San Martín, 2003: 296

Material: C5c, 1 ind.

Distribution: Mediterranean and Red Sea, Australia, E Atlantic from the North Sea to the Canary
Islands and W Atlantic Ocean from North Carolina to the Gulf of México (San Martín et al., 2008a).

Genus Haplosyllis Langerhans, 1879

Haplosyllis spongicola (Grube, 1855)

Haplosyllis spongicola, Lattig et al., 2007: 554

Material: A25a, 1 ind.; A25c, 1 ind.; B1.5a, 1 ind.; B5a, 1 ind.; B5b, 1 ind.; B5c, 1 ind.; B25b, 1 ind.; C5b, 5 ind.; C25a, 1 ind.; C25b, 1 ind.; C25c, 3 ind.

Distribution: Mediterranean Sea and European Atlantic coast; other records in temperate and tropical seas must be reviewed (Lattig et al., 2007).

Genus Syllis Lamarck, 1818

Syllis armillaris (Müller, 1776)

Typosyllis armillaris, Licher, 1999: 189

Syllis armillaris, San Martín, 2003: 423; Musco and Giangrande, 2005b: 472

Material: A1.5c, 2 ind.; A5a, 1 ind.; A5b, 3 ind.; A5c, 2 ind.; A25b, 5 ind.; B25c, 8 ind.; B5b, 1 ind.; B5c, 2 ind.; B25a, 14 ind.; B25b, 15 ind.; B25c, 27 ind.; C1.5a, 3 ind.; C1.5b, 2 ind.; $\mathrm{C} 1.5 \mathrm{c}, 2$ ind.; C5b, 7 ind.; C5c, 1 ind.; C25a, 14 ind.; $C 25 b, 23$ ind.; $C 25$ c, 13 ind.

Distribution: The species is reported as cosmopolitan (Licher, 1999). However, it is considered as a possible species complex (López et al., 2001; Musco and Giangrande, 2005b).

Syllis beneliahuae (Campoy and Alquézar, 1982) (Fig. 7)

Typosyllis beneliahuae, Licher, 1999: 47 Syllis beneliahuae, San Martín, 2003: 405

Material: A1.5c, 1 ind.; A5b, 1 ind.; B25a, 2 ind.; B25c, 1 ind.; $\mathrm{C} 1.5 \mathrm{c}, 1$ ind.

Description: Largest specimen incomplete, $14.47 \mathrm{~mm}$ long for $82 \mathrm{Chr}, 0.37 \mathrm{~mm}$ wide, $\mathrm{H}+10$ $=1.07 \mathrm{~mm}$, without colour pattern (Fig. 7A). Median antenna with 23 articles, lateral antennae with 15. Tentacular cirri with $24-15$ articles. DC1 with 40 articles; remaining DC alternating from 18 to 25-30 articles. Compound chaetae clearly bidentate numbering 6-8 in anterior, 4-5 in middle-posterior parapodia. From Chr 6 to posterior end, two pseudospinigers per fascicle measuring $32 \mu \mathrm{m}$ in anterior Chr (Fig. 7B), $62 \mu \mathrm{m}$ at mid-body (Fig. 7D), $64 \mu \mathrm{m}$ in posterior Chr. Dorsal simple chaeta slightly bidentate, marginally finely serrated; ventral simple chaeta bidentate, smooth. Aciculae three in anterior Chr, two at mid-body (Fig. 7C), one posteriorly (Fig. 7E). Proventricle rectangular extending from $\mathrm{Chr} 12$ 


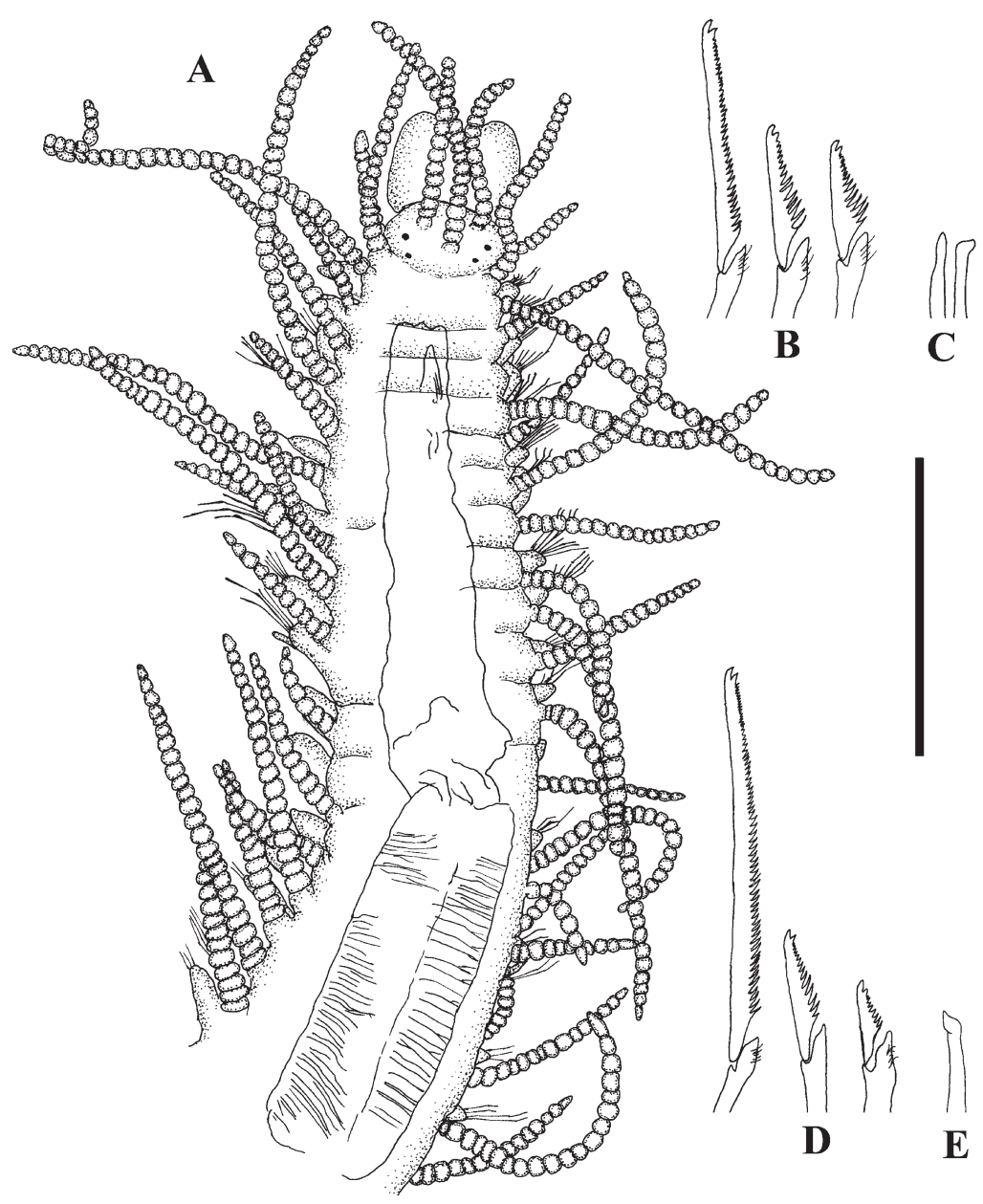

FIG. 7. - Syllis beneliahuae. A, anterior end, dorsal view; B, anterior pseudospiniger and falciger chaetae; C, mid-body aciculae; D, midposterior pseudospiniger and falciger chaetae; E, posterior aciculae. Scale bars: A, $500 \mu \mathrm{m}$; B-E, $50 \mu \mathrm{m}$.

to 19 , with 37 muscle cell rows. Pharynx extending through 11-12 segments (Fig. 7A); tooth anterior, conical to drop-shaped. Pygidium small; anal cirri with 12-13 articles.

Remarks: Our specimens agree with San Martín (2003) but differ slightly from the holotype redescription (Licher, 1999) in having somewhat shorter lateral antennae and mid-body pseudospinigers. Like $S$. rosea and S. garciai (see descriptions below), S. beneliahuae is characterized by pseudospinigers, as is $S$. cornuta (Rathke, 1843), a species commonly reported from both hard and soft bottoms in the N Adriatic (Zahtila, 1995 and references cited). However, according to Licher (1999) and San Martín (2003), this species should not be present in the Mediterranean Sea, being typical for colder regions (neotype locality Trondheimsfjorden, Norway). We herein hypothesize that the previous records of $S$. cornuta in the area, par- ticularly as far as hard bottom findings are concerned, may possibly belong to $S$. beneliahuae, $S$. rosea or/ and $S$. garciai, but also to $S$. parapari (see San Martín and López, 2000), which were not previously recorded in the N Adriatic. The descriptions of the first three species are herein given, to facilitate the identification in future research in the area. Similarly, soft bottom reports of S. cornuta in the N Adriatic Sea should be carefully reconsidered. In fact, the analysis of the $\mathrm{N}$ Adriatic soft bottom material from the Rovinj Center for Marine Research collection (unpublished data) revealed that the specimens assigned to $S$. cornuta actually belong to $S$. parapari San Martín and López, 2000, but also to $S$. garciai and S. cf. alosae San Martín, 1992. This confirms that previous findings of $S$. cornuta in the Mediterranean should probably be attributed to $S$. parapari, whose presence, however, is not formally confirmed for the Mediterranean (San Martín, 2003). 
Distribution: Mediterranean Sea, E Atlantic Ocean and Caribbean coast (Licher, 1999). New for the N Adriatic Sea.

\section{Syllis corallicola Verrill, 1900}

Typosyllis corallicola, Licher, 1999: 116

Syllis corallicola, San Martín, 2003: 439

Material: A5a, 1 ind.; A5b, 2 ind.; A5c, 4 ind.; B5a, 3 ind.; B5b, 4 ind.; $5 \mathrm{c}, 9$ ind.; C1.5a, 1 ind.; C1.5b, 8 ind.; C5a, 2 ind.; C5b, 2 ind.; C5c, 1 ind.; C25a, 1 ind.; C25b, 1 ind.; C25c, 1 ind.

Remarks: Our specimens agree with the descriptions of Licher (1999) and San Martín (2003) except in having ventral cirri as long as parapodial lobes vs shorter in Licher (1999), while anteriorly longer and posteriorly shorter than parapodial lobes in San Martín (2003). The proventricle is one third longer than the pharynx, with 26-30 muscle cell rows vs as long as the pharynx with 34-40 muscle cell rows, according to the above mentioned authors.
Distribution: Mediterranean Sea, Caribbean coast and Gulf of México, Eastern Central Pacific and W Indian Ocean (Licher, 1999). New for the N Adriatic Sea.

Syllis ferrani Alós and San Martín, 1987

Typosyllis ferrani, Licher, 1999: 221

Syllis ferrani, San Martín, 2003: 390

Material: A25a, 1 ind.; B25a, 1 ind.; B25b, 1 ind.; C25a, 1 ind.; $\mathrm{C} 25 \mathrm{~b}, 1$ ind.; $\mathrm{C} 25 \mathrm{c}, 3$ ind.

Remarks: Our specimens mostly agree with the original description (Alós and San Martín, 1987), but differ in having 5-9 compound chaetae per chaetal fascicle in anterior Chr vs 11-13 in the original description. Our specimens also have two aciculae in anterior parapodia vs 5-6 and 3-6 in Alós and San Martín (1987) and Licher (1999), respectively.

Distribution: Mediterranean Sea (Licher, 1999). New for the N Adriatic Sea.
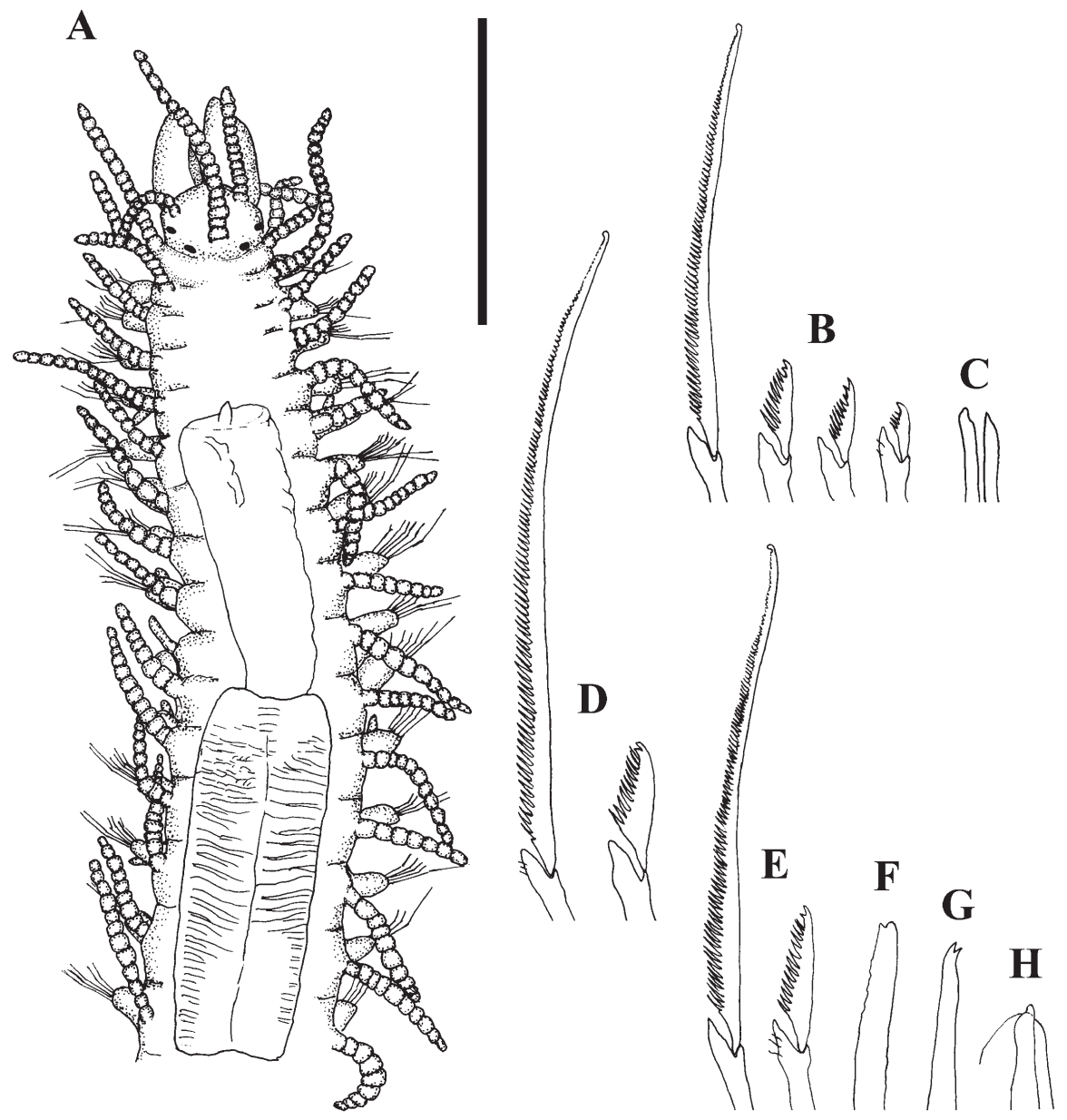

FIG. 8. - Syllis garciai. A, anterior end, dorsal view; B, anterior pseudospiniger and falciger chaetae; C, anterior aciculae; D, mid-body pseudospiniger and falciger chaetae; E, posterior pseudospiniger and falciger chaetae; F, simple dorsal chaetae; G, simple ventral chaetae; H, posterior aciculae. Scale bars: A, $500 \mu \mathrm{m} ; \mathrm{B}-\mathrm{H}, 50 \mu \mathrm{m}$. 

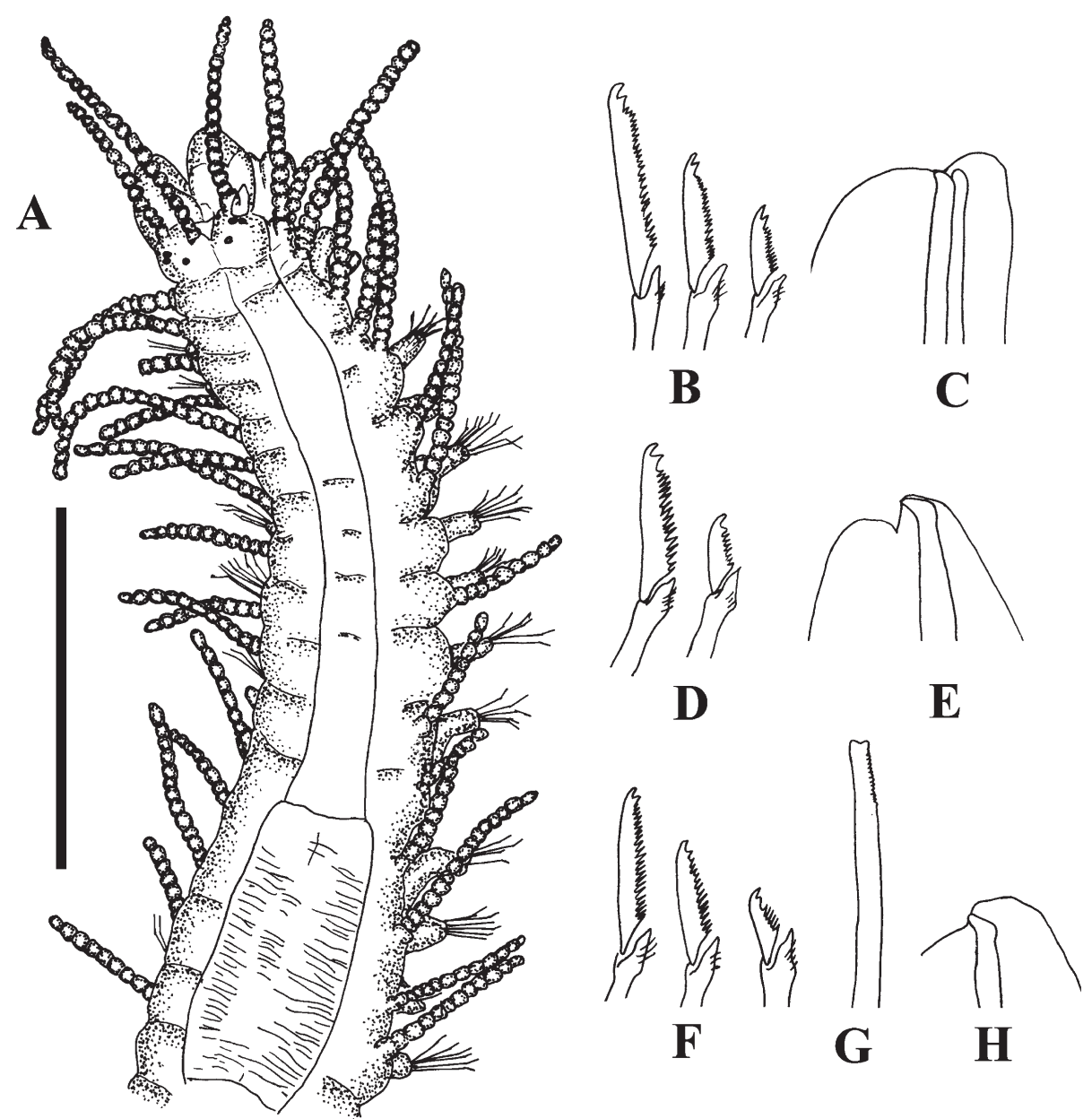

$\mathbf{E}$

FIG. 9. - Syllis gerlachi. (A) Anterior end, dorsal view; (B) Anterior falciger chaetae; (C) Anterior aciculae; (D) Mid-body falciger chaetae; (E) Mid-body aciculae; (F) Posterior falciger chaetae; (G) Simple dorsal chaetae; (H) Posterior aciculae. Scale bars: A, $500 \mu \mathrm{m}$; B-H, $50 \mu \mathrm{m}$.

Syllis garciai (Campoy, 1982)

(Fig. 8)

Typosyllis garciai, Licher, 1999: 74

Syllis garciai, San Martín, 2003: 400

Material: A5b, 1 ind.; A25c, 1 ind.; B25b, 1 ind.; C25a, 1 ind.; $\mathrm{C} 25 \mathrm{c}, 3$ ind.

Description: Largest specimen complete, 10.08 $\mathrm{mm}$ long for $72 \mathrm{Chr}, 0.28 \mathrm{~mm}$ wide, $\mathrm{H}+10=1.02$ $\mathrm{mm}$, without colour pattern (Fig. 8A). Median antenna with 18 articles, lateral with 12 . Tentacular cirri with 14-12 articles. DC1 with 19 articles; subsequent alternating in length, from 9-11 to 11-13 articles. 8-9 compound chaetae (including 3 pseudospinigers) in anterior Chr, 6 from Chr 31 backwards (including 1 pseudospiniger). Pseudospiniger blades very weakly bidentate to unidentate, $58 \mu \mathrm{m}$ long in anterior $\mathrm{Chr}$, up to $71 \mu \mathrm{m}$ at mid-body, $51 \mu \mathrm{m}$ to $81 \mu \mathrm{m}$ in posterior Chr. Spines of falciger blades reaching or overpassing blade tip, falcigers clearly bidentate (Fig.
8B, D, E). Dorsal simple chaeta truncated (Fig. 8F), ventral simple smooth, bidentate (Fig. 8G). Aciculae two in anterior, one in middle-posterior Chr (Fig. $8 \mathrm{C}, \mathrm{H})$. Proventricle rectangular extending in $\mathrm{Chr}$ 10-15, with 30 muscle cell rows (Fig. 8A). Pharynx brownish, anterior conical tooth. One female with eggs from Chr 24.

Remarks: See remarks for S. beneliahuae.

Distribution: Mediterranean Sea, Cuba (Licher, 1999). New for the N Adriatic Sea.

Syllis gerlachi Hartmann-Schröder, 1960

(Fig. 9)

Typosyllis gerlachi Hartmann-Schröder, 1960: 81; Licher, 1999: 127

Syllis truncata cryptica Ben-Eliahu, 1977: 41; San Martín, 1984: 352

Syllis gerlachi, San Martín, 2003: 376 
Material: A25a, 8 ind.; A25b, 2 ind.; A25c, 6 ind.; B5b, 2 ind.; B5c, 1 ind.; B25a, 9 ind.; B25b, 5 ind.; B25c, 14 ind.; C1.5a, 2 ind.; C5a, 1 ind.; C5c, 2 ind; C25a, 3 ind.; C25b, 8 ind.; C25c, 5 ind.

Description: Largest specimen incomplete, 7.2 $\mathrm{mm}$ long for $63 \mathrm{Chr}, 0.28 \mathrm{~mm}$ wide, $\mathrm{H}+10=0.91$ mm (Fig. 9A). Colour pattern absent after preservation. Median antenna with 20 articles, lateral with 13-15. Tentacular cirri with 16-11 articles. DC1 with 23 articles, backwards alternating in length (12-15 articles). Compound chaetae numbering 7-10 in anterior, 6-8 in middle-posterior Chr (Fig. 9B, D, F). Dorsal simple chaeta truncated; ventral simple bidentate, marginally serrated (Fig. 9G). Aciculae two in anterior Chr (Fig. 9C), one (distally bent, forming a right angle) in middle-posterior Chr (Fig. 9E, H). Proventricle rectangular, $0.4 \mathrm{~mm}$ long, 0.17 $\mathrm{mm}$ wide, extending for four segments (Chr 13-16), with 22 muscle cell rows (Fig. 9A). Pharynx 1.02 $\mathrm{mm}$ long (extending for $12 \mathrm{Chr}$ ), with an anterior, conical tooth.

Remarks: Our specimens agree with the description of San Martín (1984) of S. truncata cryptica, which was originally described from the Gulf of Elat, Red Sea (Ben-Eliahu, 1977) and subsequently commonly recorded in the Mediterranean Sea. However, this sub-species was considered as a synonym of S. gerlachi by Licher (1999), who described $S$. gerlachi by combining the characters of an incomplete syntype from the Red Sea (lacking the last segments) and those listed in the original description (Hartmann-Schröder, 1960). Our specimens differ from the original description in having posterior DC with 12-15 articles, compared with 6-8 in Hartmann-Schröder (1960) and in having a pharynx/proventricle length ratio of 3 , vs 1.4 and 1.6 respectively in the original descriptions of $S$. gerlachi and S. truncata cryptica. In Licher (1999), the pharynx is even shorter than the proventricle. Although we consider these differences as intraspecific, further analyses are needed, particularly of alive specimens from the Red Sea type locality. In fact, irregularly arranged faintly marked orange dorsal spots, which completely disappear after preservation, were observed in the live specimens of S. gerlachi from the N Ionian Sea (LM, personal observation).

Distribution: Mediterranean and Red Sea, Indian Ocean, Caribbean coast, Gulf of México (Licher, 1999). New for the N Adriatic Sea.
Syllis gracilis Grube, 1840

Syllis gracilis, San Martín, 2003: 413

Material: A25a, 8 ind.; A25b, 2 ind.; A25c, 6 ind.; B5b, 2 ind.; B5c, 1 ind.; B25a, 9 ind.; B25b, 5 ind.; B25c, 14 ind.; C1.5a, 2 ind.; C5a, 1 ind.; C5c, 2 ind; C25a, 3 ind.; C25b, 8 ind.; C25c, 5 ind.

Distribution: Cosmopolitan in warm-temperate areas (San Martín, 2003). According to Maltagliati et al. (2000) $S$. gracilis is a sibling species complex.

\section{Syllis krohni Ehlers, 1864}

Typosyllis krohni, Licher, 1999: 205

Syllis krohnii, San Martín, 2003: 386

Material: A1.5a, 4 ind.; A1.5b, 2 ind.; B5c, 1 ind.; C1.5b, 2 ind.; $\mathrm{C} 1.5 \mathrm{c}, 1$ ind.

Distribution: Mediterranean and North Sea, N Atlantic and Central-East Atlantic Ocean; records outside the above mentioned areas are considered doubtful (Licher, 1999).

\section{Syllis prolifera Krohn, 1852}

Typosyllis prolifera, Licher, 1999: 135 Syllis prolifera, San Martín, 2003: 344

Material: A5b, 11ind.; A5c, 4 ind.; B1.5a, 12 ind.; B1.5b, 4 ind.; $\mathrm{B} 1.5 \mathrm{c}, 13$ ind.; $\mathrm{B} 5 \mathrm{a}, 1$ ind.; B5b, 12 ind.; $\mathrm{B} 5 \mathrm{c}, 13$ ind.; B25b, 5 ind.; C1.5a, 1 ind.; C1.5b, 19 ind.; C5b, 6 ind.; C5c, 1 ind.; C25a, 1 ind.; $\mathrm{C} 25 \mathrm{c}, 3$ ind.

Distribution: Cosmopolitan (Licher, 1999).

Syllis rosea (Langerhans, 1879)

(Fig. 10)

Typosyllis rosea, Licher, 1999: 44

Syllis rosea, San Martín, 2003: 358

Material: A1.5a, 4 ind.; A1.5b, 39 ind.; A1.5c, 3 ind.; A5b, 1 ind.; $\mathrm{A} 5 \mathrm{c}, 1$ ind.; B1.5a, 2 ind.; B1.5b, 10 ind.; B1.5c, 2 ind.; B5a, 1 ind.; $\mathrm{C} 1.5 \mathrm{a}, 2$ ind.; $\mathrm{C} 1.5 \mathrm{c}, 1$ ind.; $\mathrm{C} 5 \mathrm{~b}, 1$ ind.

Description: Specimen complete, $8.64 \mathrm{~mm}$ long for $66 \mathrm{Chr}, 0.33 \mathrm{~mm}$ wide, $\mathrm{H}+10=1.02 \mathrm{~mm}$ (Fig. 10A). Colour pattern absent. Median antenna with 16 articles, lateral with 16 . Peristomium short, about half long as Chr1. Dorsal tentacular cirri with 19 articles; ventral with 13 . DC1 with 17 articles; backward alternating from 15 to 20 . Anterior $\mathrm{Chr}$ with 7-8 compound chaetae (1-2 with longer blade, $30 \mu \mathrm{m}) ; 6$ at mid-body (1 with pseudospiniger appearance, $60 \mu \mathrm{m})$; 5-6 in posterior Chr (1-2 pseu- 


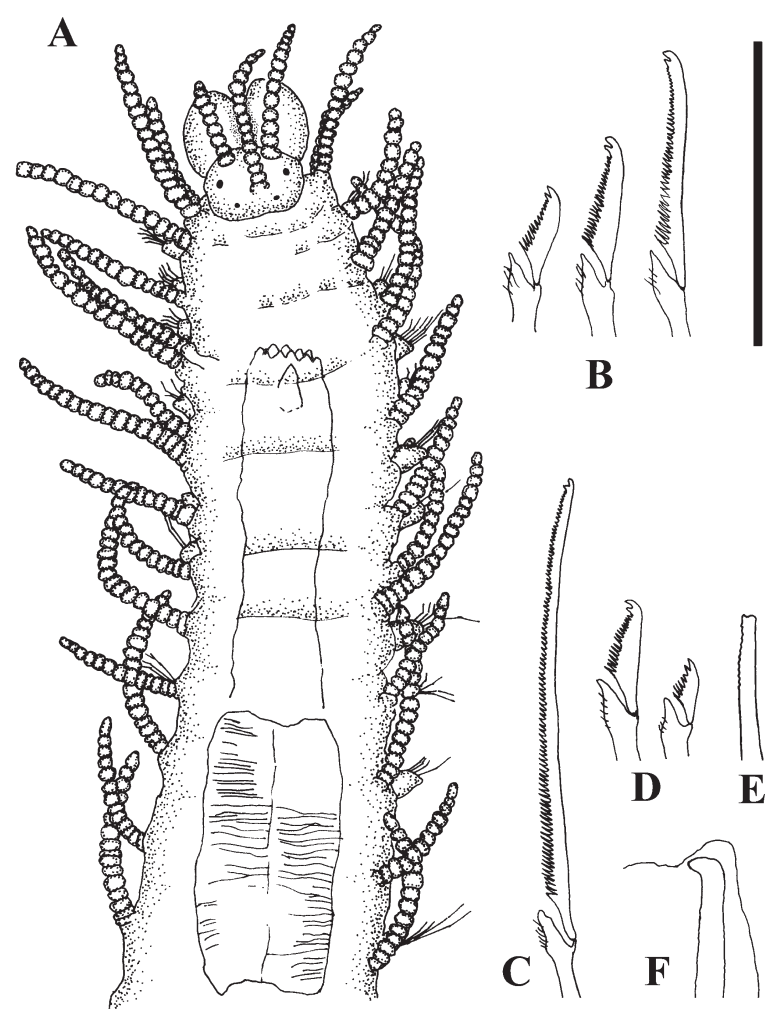

FIG. 10. - Syllis rosea. (A) Anterior end, dorsal view; (B) Anterior chaetae; (C) Mid-posterior pseudospiniger chaetae; (D) Midposterior falciger chaetae; (E) Posterior simple dorsal chaetae; (F) Posterior aciculae. Scale bars: A, $500 \mu \mathrm{m} ; \mathrm{B}-\mathrm{F}, 50 \mu \mathrm{m}$.

dospinigers $81 \mu \mathrm{m}$ ) (Fig. 10B, C, D). Chaetae bidentate, bidentation of pseudospinigers progressively reduced backwards. Dorsal simple truncated chaeta from Chr 59 (Fig. 10E). Aciculae two in anterior, one in middle-posterior $\mathrm{Chr}$, distally bent at a right angle (Fig. 10F). Proventricle rectangular extending through 3-4 segments (Chr 11-13), with 25 muscle cell rows. Tooth conical to drop shaped, anteriorly in the pharynx.

Remarks: Our specimens differ from San Martín (2003), particularly in having dorsal and ventral tentacular cirri somewhat longer. See also remarks for S. beneliahuae.

Distribution: Mediterranean Sea, Madeira and Canary Islands, NW Pacific Ocean and Solomon Islands (Licher, 1999). New for the N Adriatic Sea.

Syllis variegata Grube, 1860

Typosyllis variegata, Licher, 1999: 101

Syllis variegata, San Martín, 2003: 351

Material: A5a, 7 ind.; A5b, 2 ind.; A25b, 1 ind.; A5a, 4 ind.; A5b,
4 ind.; A5c, 2 ind.; B25a, 4 ind.; B25b, 3 ind.; B25c, 2 ind.; C1.5a, 1 ind.; C1.5b, 1 ind.; C1.5c, 1 ind.; C5a, 2 ind.; C 5 b, 4 ind.; C 5 c, 5 ind.; $\mathrm{C} 25 \mathrm{a}, 4$ ind.

Remarks: Our specimens agree with the holotype redescription by Licher (1999). The type locality (Krk Island) is close to our research area. As in Licher (1999), our specimens were generally dark, mostly lacking the typical "eyeglasses-shaped" colour pattern, possibly due to preservation. However, the specimens from Sveti Ivan Island bear stout, short, fusiform mid-posterior DC, resembling $S$. ferrani, while Licher (1999) reports slim middleposterior DC, scarcely attenuating towards the tip. Also, the simple dorsal chaeta is straight and distally serrated, while slightly curved and smooth in Licher (1999). Thus, our specimens better correspond to the Iberian specimens described by San Martín (2003). All above differences, as well as those between Licher (1999) and San Martín (2003) (i.e. number, length and dorso-ventral gradation of anterior chaetae, number of proventricular muscle cell rows, length of anterior dorsal cirri and ventral cirri), are herein considered as intra-specific variations.

Distribution: Cosmopolitan (Licher, 1999).

\section{Syllis westheidei San Martín, 1984}

Syllis westheidei San Martín, 1984: 403; San Martín, 2003: 436 Typosyllis westheidei, Licher, 1999: 111

Material: B1.5a, 6 ind.; B1.5b, 1 ind.; B1.5c, 6 ind.; B5a, 1 ind.; B5b, 3 ind.; B5c, 3 ind.; C1.5a, 1 ind.; C5c, 1 ind.

Distribution: Mediterranean Sea, Red Sea (Gulf of Akaba) (Licher, 1999). New for the N Adriatic Sea.

Genus Trypanosyllis Claparède, 1864

Trypanosyllis coeliaca Claparède, 1868

Trypanosyllis coeliaca, San Martín, 2003: 308

Material: A1.5a, 1 ind.; A1.5c, 1 ind.; B1.5a, 2 ind.; B1.5b, 1 ind.; $\mathrm{B} 1.5 \mathrm{c}, 1$ ind.; B5c, 1 ind.; $\mathrm{C} 1.5 \mathrm{c}, 1$ ind.; $\mathrm{C} 25 \mathrm{~b}, 1$ ind.

Remarks: Pseudosyllis brevipennis Grube, 1863 and Tetraglene rosea Grube, 1863 were considered nomina dubia and synonyms of $T$. coeliaca (San Martín, 2003).

Distribution: Mediterranean Sea, Atlantic Ocean and Pacific Marquesas Islands (San Martín, 2003). 
Trypanosyllis zebra (Grube, 1860)

Trypanosyllis zebra, San Martín, 2003: 311; San Martín et al., 2008b: 43

Material: A5b, 1 ind.; B5a, 1 ind.; C1.5a, 1 ind.; C1.5b, 1 ind.; C5c, 1 ind.

Distribution: Cosmopolitan in temperate and tropical seas (San Martín et al., 2008b).

Genus Xenosyllis Marion and Bobretzky, 1875 Xenosyllis scabra (Ehlers, 1864)

Xenosyllis scabra, San Martín, 2003: 303

Material: A5b, 1 ind.; B5a, 2 ind.; B5c, 2 ind.; $\mathrm{C} 1.5 \mathrm{a}, 1$ ind.; $\mathrm{C} 1.5 \mathrm{~b}$, 1 ind.; C1.5c, 1 ind.; C5b, 1 ind.; C5c, 1 ind.

Remarks: Reports of this species beyond the type locality should be re-examined, as they may represent other species (San Martín et al., 2008a). The European specimens present intra-specific chaetal variation, having either unidentate blades only or both unidentate and bidentate blades (Campoy, 1982). Our specimens agree with San Martín (2003), in having ventral-most unidentate and dorsal-most bidentate blades.

Distribution: Mediterranean Sea, European Atlantic coasts (San Martín, 2003).

\section{DISCUSSION}

Similarly to the polychaete assemblages of Otranto in the extreme south Adriatic Sea (Giangrande et $a l ., 2003)$, the Sveti Ivan syllid assemblages are variable in terms of both species abundance and richness among depths and their horizontal distribution. At the considered spatial scale (hundreds of metres), in fact, this spatial variability is a common trend in benthic assemblages, and has already been reported for the Syllidae (Musco et al., 2009).

From a faunistic point of view, 13 species are newly recorded for the northern Adriatic Sea, increasing the number from 53 (Castelli et al., 2008) to 66 . The number of species found in this study (39) is close to those from other Mediterranean hard bottoms (about 40 to 60 species) (Çinar, 2003; Giangrande et al., 2003; Corriero et al., 2004; López and Gallego, 2006; Musco et al., 2009), although our sampled area was considerably smaller and some specimens were possibly lost since the airlift sam- pler was not used. Moreover, the estimated number of species in our study area (from 43 to 63) suggests that its potential diversity is among the highest recently reported for the Mediterranean. Therefore, the northern Adriatic syllid assemblages appear to be complex and highly diverse, thus calling for regular faunal updating in the area (Musco and Giangrande, 2005a). Many species were, in fact, rare and the analyses of distribution patterns indicate that additional sampling would probably yield more species. Since one third of the records are new, we may assume that more new species will be further found in the northern Adriatic. Particularly, some newly recorded species were among the most abundant or frequent ones (e.g. Syllis rosea, S. gerlachi and $S$. corallicola), with Sphaerosyllis pirifera being the dominant one. Species dominating the Sveti Ivan syllid assemblages are also common and abundant in other Mediterranean areas, such as the northern Cyprus coast (Çinar, 2003) and the southern Adriatic coast (Giangrande et al., 2003).

Obviously, new northern Adriatic records represent the northward widening of the species distribution in the Mediterranean, particularly for the typically warmer (e.g. Syllis corallicola, S. gerlachi, S. garciai and S. westheidei) or endemic (e.g. S. ferrani and Exogone rostrata) ones. The presence of Branchiosyllis exilis is particularly relevant, since the whole genus is typically circumtropical.

Our study draws a scenario differing from the traditionally reported northern Adriatic one. When the species compositions are considered (faunistic analysis), Sveti Ivan is the farthest sector of the northern Adriatic. The relative positions of the Mediterranean sectors (excluding Sveti Ivan) resemble the pattern reported in Musco and Giangrande (2005a), who suggested an influence of both the different environmental features and, especially, of the taxonomic updating of the respective inventories (particularly for NA, ES and IS). Therefore, we suggest that the position of Sveti Ivan in the bi-plot might be due to its recent taxonomic updating. However, the area is represented by only one sampling time, so the potential finding of additional species in further surveys would possibly influence its degree of faunal similarity with the other sectors. The bioclimatic approach reveals that the species array at Sveti Ivan Island resembles the more southern Mediterranean syllid inventories rather than the previously reported northern Adriatic ones (dominated by cold-temperate species). 
The high number of new records of warm-water species in our study might reflect a "meridionalization" of the northern Adriatic fauna (Bianchi, 2007; Boero et al., 2008), at least for the considered depth range, since no clear differences in the bioclimatic composition among depths were observed. However, the new records might also reflect incorrect characterization of species' distributional ranges, due to lack of recent taxonomic research in the area (Musco and Giangrande, 2005a). Some species, such as Syllis beneliahuae, S. ferrani, S. garciai and $S$. westheidei, may have not been recorded previously, as former taxonomic studies of hard bottoms in the northern Adriatic Sea (Banse, 1959; Amoureux and Katzmann, 1971; Katzmann, 1971, 1972; Požar, 1972; Amoureux, 1975) were carried out before those species had been scientifically described. However, the same reason cannot justify the absence of other newly reported but well-known species, such as Myrianida convoluta, $M$. quindecimdentata, Exogone rostrata and, particularly, the abundant Sphaerosyllis pirifera, Syllis gerlachi, S. corallicola and $S$. rosea. Our findings might suggest an actual faunal change in the area.

Misidentification, most probably caused by the fact that taxonomic information currently available was not complete at the time of the former observations, is another possible reason for the lack of previous records of some species (see remarks for $S$. beneliahuae).

Whatever is the reason for the high number of new records (lack of taxonomic studies, meridionalization, misidentification), regular updates of the northern Adriatic Sea biota are important for a better understanding of the dynamics of this part of the Mediterranean, presumably highly sensitive to the influence of global warming (CIESM, 2008). The greatest problem in trying to relate changes in marine communities to climate changes is the lack of long-term data (Southward, 1995), concerning both the biota and the environmental parameters. Longterm monitoring studies of benthic fauna associated with measurements of the environmental variables in the northern Adriatic Sea, such as temperature, salinity, chlorophyll-a concentration and $\mathrm{pH}$, are necessary in order to correlate climate changes with those of the polychaete fauna and thus support the postulated meridionalization. Further studies might, in fact, clarify whether the northern Adriatic is going through species enrichment due to the establishment of warm-water species, whose high abundance might contribute to a loss of the peculiar biogeographical features of this area.

\section{ACKNOWLEDGEMENTS}

Special thanks are due to Adriana Giangrande for engagement in bilateral cooperation between Croatian and Italian Institutions, and to Ferdinando Boero and Ana Travizi for overall support. The comments of Guillermo San Martín, an anonymous referee, and particularly those of Daniel Martin, greatly improved the quality of this paper. Thanks to Andrej Jaklin and Ugo Ušić for helping with material sampling and sorting. The author BM received a scholarship from the Italian Government in the framework of the bilateral cooperation with the Republic of Croatia. The work of the author LM was financed by the Project ACTIBIOMAR (www.actibiomar. it) granted by the Apulia Region and carried out within the MARBEF Network of Excellence, which is funded in the Community's Sixth Framework Programme (contract no. GOCE-CT-2003-505446), the EU Integrated Project SESAME and the CMCC (Centro Euro-Mediterraneo per i Cambiamenti Climatici).

\section{REFERENCES}

Aleffi, F., N. Bettoso and V. Solis-Weiss. - 2003. Spatial distribution of soft-bottom polychaetes along western coast of the northern Adriatic Sea (Italy). Ann. Ser. Hist. Nat., 13(2): 211-222.

Alós, M.C. and G. San Martín. - 1987. Descripción de Syllis ferrani n. sp.: nuevo Syllidae (Annelida: Polychaeta) en el Mediterráneo. Publ. Depart. Zool., Univ. Barcelona, 7: 21-27.

Amoureux, L. - 1975. Annélides polychètes de l'ilot de Banjole (Près de Rovinj, haute-Adriatique). Cah. Biol. Mar., 16: 231-244.

Amoureux, L. - 1983. Les Annélides Polychètes de la Mer Adriatique. Thalassia Jugosl., 19: 7-13.

Amoureux, L. and W. Katzmann. - 1971. Note faunistique et écologique sur une collection d'Annélides Polychètes de substrats rocheux circalittoraux de la région de Rovinj (Yugoslavie). Zool. Anz., 186(1/2): 114-122.

Anderson, M.J. - 2005. PERMANOVA: a FORTRAN Computer Program for Permutational Multivariate Analysis of Variance. Department of Statistics, University of Auckland, New Zealand. Available at: www.stat.auckland.ac.nz/ mja/Programs.htm

Banse, K. - 1959. Polychaeten aus Rovinj (Adria). Zool. Anz., 169: 295-313.

Ben-Eliahu, M.N. - 1977. Polychaete cryptofauna from rims of similar intertidal vermetid reefs on the Mediterranean coast of Israel and in the Gulf of Elat: Syllinae and Eusyllinae (Polychaeta Errantia: Syllidae). Isr. J. Zool., 26: 1-58.

Bianchi, C.N. - 2007. Biodiversity issues for the forthcoming tropical Mediterranean Sea. Hydrobiologia, 580: 7-21.

Bianchi, C.N., F. Boero, S. Fraschetti and C. Morri. - 2004. The wildlife of the Mediterranean. In: A. Minelli, C. Chemini, R. Argano and S. Ruffo (eds.), Wildlife in Italy, pp. 248-335. Touring Editore, Milan - Italian Ministry for the Environment and Territory, Rome. 
Boero, F. and E. Bonsdorff. - 2007. A conceptual framework for marine biodiversity and ecosystem functioning. Mar. Ecol.Evol. Persp., 28(Suppl. 1): 134-145.

Boero, F., J.P. Féral, E. Azzurro, V. Cardin, B. Riedel, M. Despalatović, I. Munda, P. Moschella, J. Zaouali, S. Fonda Umani, A. Theocharis, K. Wiltshire and F. Briand. - 2008. Climate warming and related changes in Mediterranean marine biota. In: F. Briand (ed.) Climate warming and related changes in Mediterranean marine biota, Vol 35, pp. 5-21. CIESM Workshop Monographs, Monaco.

Campoy, A. - 1982. Fauna de España. Fauna de anélidos poliquetos de la Península Ibérica. EUNSA, Publicaciones de Biología de la Universidad de Navarra, Serie Zoológica, 7(1), pp. 1-781. Pamplona.

Castelli, A., S. Massei, A. Valentini and R. Crema. - 1999. Distribuzione dei policheti di fondi molli del Medio e dell'Alto Adriatico. Biol. Mar. Medit., 6(1): 358-361.

Castelli, A., C.N. Bianchi, G. Cantone, M.E. Cinar, M.C. Gambi, A. Giangrande, D. Iraci Sareri, P. Lanera, M. Licciano, L. Musco, R. Sanfilippo and R. Simonini - 2008. Annelida Polychaeta. In: G. Relini (ed.) Checklist della flora e della fauna dei mari italiani (Parte I). Biol. Mar. Medit., 15(Suppl. 1): 323-373.

CIESM. - 2008. Climate warming and related changes in Mediterranean marine biota, Vol. 35, pp. 1-152. F. Briand (ed.). CIESM Workshop Monographs, Monaco.

Çinar, M.E. - 2003. Ecology of Syllidae (Annelida: Polychaeta) from northern Cyprus (eastern Mediterranean Sea). Bull. Mar. Sci., 72(3): 795-811.

Corriero, G, M. Gherardi, A. Giangrande, C. Longo, M. Mercurio, L. Musco and C. Nonnis Marzano. - 2004. Inventory and distribution of hard bottom fauna from the Marine Protected Area of Porto Cesareo (Ionian Sea): Porifera and Polychaeta. Ital. J. Zool., 71: 237-245.

Giangrande, A., A.L. Delos, S. Fraschetti, L. Musco, M. Licciano, A. Terlizzi. - 2003. Polychaetes assemblages along a rocky shore on the South Adriatic coast (Mediterranean Sea): patterns of spatial distribution. Mar. Biol., 143: 1109-1116.

Giangrande, A., A.L. Delos, L. Musco, M. Licciano and C. Pierri. - 2004. Polychaete assemblages of rocky shore along the South Adriatic coast (Mediterranean Sea). Cah. Biol. Mar., 45: 85-95.

Gravier, C - 1900. Contribution à l'étude des Annélides Polychètes de la Mer Rouge. Nouv. Archs Mus. Hist. Nat., Paris, (Ser.4), 2: $137-282$.

Hartmann-Schröder, G. - 1960. Polychaeten aus dem Roten Meer. Kieler Meeresforsch., 16: 69-125.

Katzmann, W. - 1971. Polychaeten (Errantier, Sedentarier) aus nordadriatischen Cystoseira-Beständen und deren Epiphyten. Oecologia, 8: 31-51.

Katzmann, W. - 1972. Die Polychaeten Rovinjs (Istrien/Jugoslawien). Zool. Anz., 188(1/2): 116-144.

Lattig, P., G. San Martín and D. Martin . - 2007. Taxonomic and morphometric analyses of the Haplosyllis spongicola complex (Polychaeta: Syllidae: Syllinae) from Spanish seas, with re-description of the type species and descriptions of two new species. Sci. Mar., 71(3): 551-570.

Licher, F. - 1999. Revision der Gattung Typosyllis Langerhans, 1879 (Polychaeta: Syllidae). Morphologie, Taxonomie und Phylogenie. Abh. Senckenb. Natforsch. Ges., 551: 1-336.

López, E., T.A. Britayev, D. Martin and G. San Martín. - 2001. New symbiotic associations involving Syllidae (Annelida: Polychaeta), with taxonomic and biological remarks on Pionosyllis magnifica and Syllis cf. armillaris. J. Mar. Biol. Ass. UK, 81: 399-409.

López, E. and R. Gallego. - 2006. Temporal variation of a syllid (Syllidae: Polychaeta) taxocoenosis associated with Stypocaulon scoparium (Stypocaulaceae: Phaeophyceae) in the western Mediterranean. J. Mar. Biol. Ass. UK, 86(1): 51-59.

Maltagliati, F., A.P. Paru, M. Casu, F. Rossi, C. Lardicci, M. CuriniGalletti and A. Castelli. - 2000. Is Syllis gracilis (Polychaeta: Syllidae) a species complex? An allozyme perspective. Mar. Biol., 136(5): 871-897.

McKinney, F. - 2007. The Northern Adriatic Ecosystem: Deep Time in a Shallow Sea. Columbia University Press.
Mistri, M., E.A. Fano, F. Ghion and R. Rossi. - 2002. Disturbance and Community Pattern of Polychaetes Inhabiting Valle Magnavacca (Valli di Comacchio, Northern Adriatic Sea, Italy). PSZN I: Mar. Ecol., 23(1): 31-49.

Musco, L. and A. Giangrande. - 2005a. Mediterranean Syllidae (Annelida: Polychaeta) revisited: biogeography, diversity and species fidelity to environmental features. Mar. Ecol. Prog. Ser., 304: 143-153.

Musco, L. and A. Giangrande. - 2005b. A new sponge-associated species, Syllis mayeri n. sp. (Polychaeta: Syllidae), with a discussion on the status of S. armillaris (Müller, 1776). Sci. Mar., 69: 467-474.

Musco, L., A. Giangrande, M. Gherardi, E. Lepore, M. Mercurio and M. Sciscioli. - 2008. Sperm ultra-structure of Odontosyllis ctenostoma (Polychaeta: Syllidae) with inferences on syllid phylogeny and reproductive biology. Sci. Mar., 72(3): 421-427.

Musco, L., A. Terlizzi, M. Licciano and A. Giangrande. - 2009. Taxonomic structure and the effectiveness of surrogates in environmental monitoring: a lesson from polychaetes. Mar. Ecol. Prog. Ser., 383: 199-210.

Núñez, J. and G. San Martín. - 1991. Two new species of Syllidae (Polychaeta) from Tenerife (Canary Island, Spain). Bull. Mar. Sci., 48(2): 236-241.

Nygren, A. - 2004. Revision of Autolytinae (Syllidae: Polychaeta). Zootaxa, 680: 1-314.

Požar, A. - 1972. Polychaeta obraštajnih životnih zajednica na različitim podlogama. Rad JAZU, 364: 39-45.

Požar-Domac, A. - 1994. Index of the Adriatic Sea polychaetes (Annelida, Polychaeta). Nat. Croat., 3: 1:23.

San Martín, G. - 1984. Estudio biogeográfico, faunístico y sistemático de los Poliquetos de la familia Sílidos (Syllidae: Polychaeta) en Baleares. Publ. Univ. Complutense Madrid.

San Martín, G. - 2003. Annelida, Polychaeta II: Syllidae. In: M.A. Ramos, J. Alba, X. Bellés, J. Gosálbez, A. Guerra, E. Macpherson, F. Martín, J. Serrano and J. Templado (eds.), Fauna Ibéri$c a$, Vol 21, pp. 1-554. Museo Nacional de Ciencias Naturales, CSIC, Madrid.

San Martín, G. - 2005. Exogoninae (Polychaeta: Syllidae) from Australia with the description of a new genus and twenty-two new species. Rec. Aust. Mus., 57: 39-152.

San Martín, G. and E. López. - 2000. Three new species of Syllis (Syllidae: Polychaeta) from Iberian coasts. Cah. Biol. Mar., 41: 425-433.

San Martín, G. and P.A. Hutchings. - 2006. Eusyllinae (Polychaeta, Syllidae) from Australia with the description of a new genus and fifteen new species. Rec. Aust. Mus., 58(3): 257-370.

San Martín, G., P. Hutchings and M.T. Aguado. - 2008a. Syllinae (Polychaeta: Syllidae) from Australia. Part 1. Genera Branchiosyllis, Eurysyllis, Karroonsyllis, Parasphaerosyllis, Plakosyllis, Rhopalosyllis, Tetrapalpia n.gen., and Xenosyllis. Rec. Aust. Mus., 60: 119-160.

San Martín, G., P. Hutchings and M.T. Aguado. - 2008b. Syllinae (Polychaeta: Syllidae) from Australia. Part 2. Genera Inermosyllis, Megasyllis n. gen., Opisthosyllis, and Trypanosyllis. Zootaxa, 1840: 1-53.

San Martín G., López, E. and M.T. Aguado. - 2009. Revision of the genus Pionosyllis (Polychaeta: Syllidae: Eusyllinae), with a cladistic analysis, and the description of five new genera and two new species. J. Mar. Biol. Ass. UK, doi:10.1017/ S0025315409003099.

Southward, A.J. - 1995. The importance of long time-series in understanding the variability of natural systems. Helgol. Meeresunters., 49: 329-333.

Zahtila, E. - 1995. Ekološka i biogeografska analiza faune mnogočetinaša (Annelida, Polychaeta) Jadranskog mora. Ph. D. thesis, Univ. Zagreb, Croatia.

Zahtila E. - 1997. Offshore polychaete fauna in the northern Adriatic with trophic characteristic. Period. Biol., 99(2): 213-217.

Scient. ed.: D. Martin.

Received May 25, 2009. Accepted October 7, 2009.

Published online March 19, 2010. 